\title{
An Insight on Analytical Profile on Bisoprolol Fumarate - A Selective Beta-1 Adrenoreceptor Blocker
}

\author{
AJINKYA G. DHANDAR, SURAJ R. CHAUDHARI, SAURABH B. GANORKAR, \\ AMOD S. PATIL, SANJAY J. SURANA AND ATUL A. SHIRKHEDKAR* \\ R.C. Patel Institute of Pharmaceutical Education and Research, Shirpur, Dist. Dhule, \\ India
}

\section{*Email: shirkhedkar@gmail.com}

Received: June 15, 2017 | Revised: July 19, 2017 I Accepted: Sept. 22, 2017

Published online: Nov. 02, 2017

The Author(s) 2017. This article is published with open access at www.chitkara.edu.in/publications

\begin{abstract}
BF is Beta-adreno receptor antagonist and used as an AntiHypertensive Drug. BF gives the blocking action on $\beta 1$-adrenergic receptors in the heart and vascular smooth muscle. The present review compiles the various approaches implemented for quantification of BF in bulk drug, pharmaceutical matrix and biological fluid. This review represents more than 50 analytical methods which include capillary electrophoresis, HPLC, HPTLC, UV-Spectroscopy, UPLC, impurity profiling and electrochemical methods implemented for estimation of BF as a single component as well as in multicomponent.
\end{abstract}

Keyword: BF; Bioanalytical; UPLC/LC-MS; capillary electrophoresis; impurity profile

\section{INTRODUCTION}

$\mathrm{BF}$ is an extremely discriminatory $\beta 1$-adrenergic blocker [1]. BF is chemically: $(R S)-1-[4-[[2-(1-$ Methylethoxy) ethoxy] methyl] phenoxy] -3-[(1 methyl ethyl) amino] propan-2-ol fumarate Figure 1. It is official in, USP. BF has similar structure to metoprolol, bopindolol, hydrochlorothiazide, atenolol [2]. Structure of BF, there is two substituents at para position of benzene provide the activity of $\beta$-selectivity, In which it has two substituents in para position of benzene which might be the activity of $\beta$ - selectivity [3]. White crystalline powder of BF was soluble in water, methanol, ethanol, and chloroform. [4]. BF blocks catecholamine stimulus of $\beta 1$-adrenergic receptors in the heart (cardio-selective) and

Journal of Pharmaceutical Technology, Research and Management Vol-5, No-2, November 2017 pp. 185-216 
Dhandar, A.G. Chaudhari, S.R. Ganorkar, S.B. Patil, A.S.

Surana, S.J. Shirkhedkar, A.A.

vascular smooth muscle, with decreasing the heart rate, cardiac output, systolic and diastolic blood pressure, and may be response orthostatic hypotension [5]. $\beta$-Blocker with calcium channel blocker mixture has efficacy in definite cardiovascular diseases like angina pectoris, myocardial infarction and hypertension [4]. For the decrease of workload on the heart and hence oxygen demands, so that the drug is pointed toward for secondary prevention of myocardial infarction, parallel therapy in patients with stable chronic heart failure, and for the treatment of hypertension and angina pectoris[5]. About $80 \%$ bioavailability given by $\mathrm{BF}$ after $10 \mathrm{mg}$ oral dose[6]. The first pass metabolism of BF is about $20 \%$ and binding to serum proteins is approximately $30 \%$ [5]. The concentrations of plasma were taken in between $5 \mathrm{mg}$ to $20 \mathrm{mg}$. It is contraindicated in person suffering from Psoriasis, Myasthenia Gravis, Sinus bradycardia, diabetes, depression and during Pregnancy. BF is available in combination with other drugs like HCT, AMD B, IRBE, CELI, METO T [7].

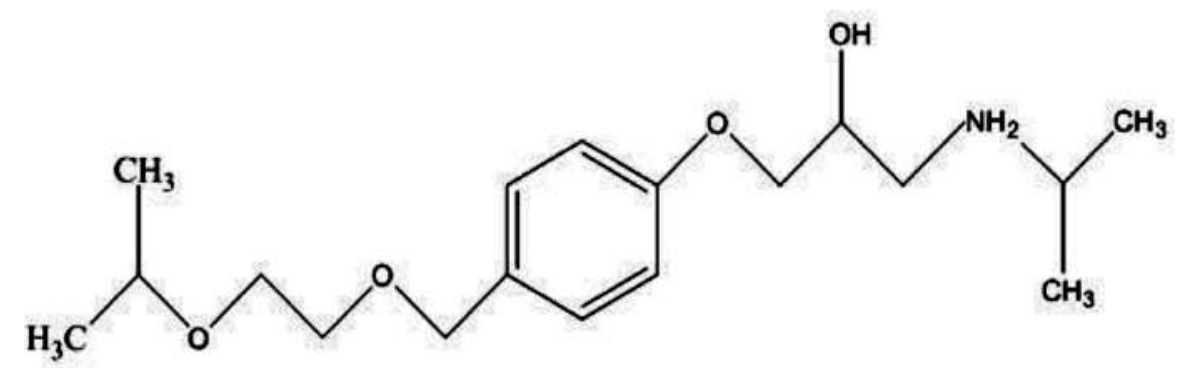

Figure 1: Chemical structure of BF.

\section{ANALYTICAL ACCOUNTS ON BF}

A variety of analytically urbanized methods like UV/Vis-Spectrophotometry, High-Performance Liquid Chromatography (HPLC), High-Performance Thin-Layer chromatography (HPTLC), Ultra Pressure Liquid Chromatography(UPLC), Liquid Chromatography-Mass Spectrometry (LCMS), Capillary Electrophoresis and Stability indicating methods have been studied for analysis of BF. The present papers described consolidate analytical methods published so far estimation of BF in bulk and pharmaceutical formulation as well as in biological samples. In literature reported method describe the analysis of $\mathrm{BF}$ in various dosage forms as single components as well as in combination with HCT, AMD B, IRBE, CELI, METO T, tropaeolin and Bromocresol green. Summary of these methods for determination of BF is shown in Figure 2. 


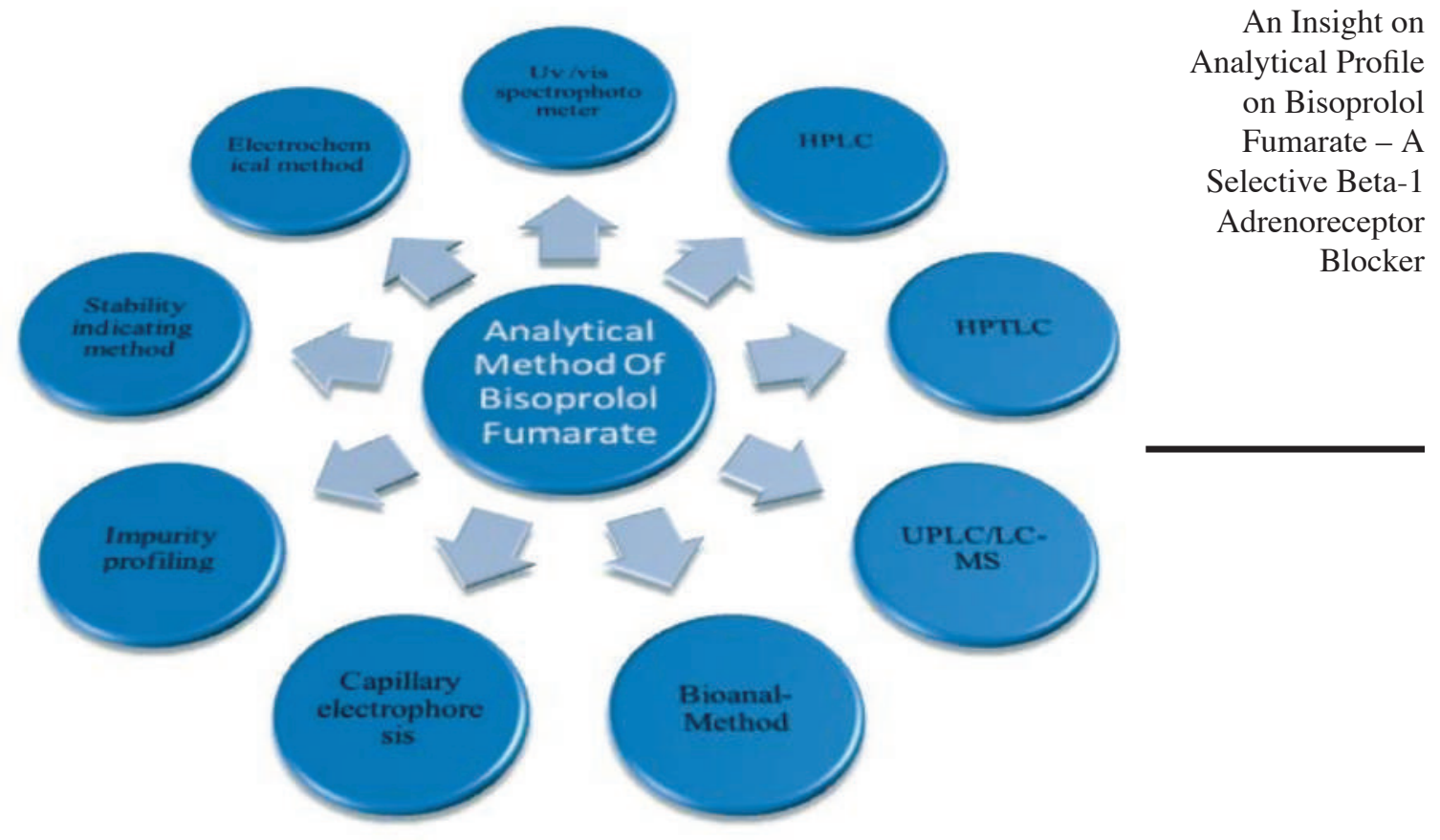

Figure 2: Analytical methods for BF.

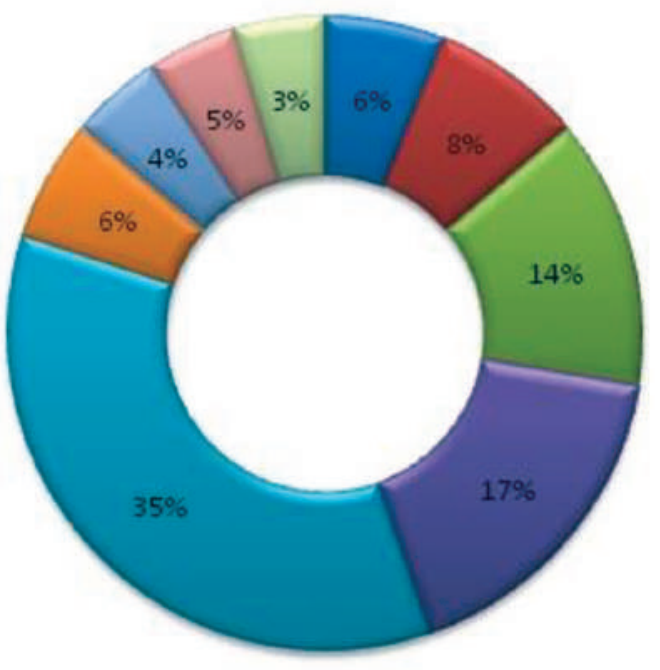

DUPLC/LC-MS

alillary electrphoresis

Bioanalytical

घUV

ㅂPLC

Gtability

口 HPTLC

घImpurity

Welectrochemical

Figure 3: \% Utility of analytical Techniques for BF. 
Dhandar, A.G.

Chaudhari, S.R.

Ganorkar, S.B.

Patil, A.S.

Surana, S.J.

Shirkhedkar, A.A.

\section{PHARMACOPOEIAL STATUS}

BF is the official drug in the (USP29) united state of pharmacopeia (2004). USP reported HPLC assay method using $4.6 \mathrm{~mm} \times 12.5 \mathrm{~cm}$ column that contain packing L7 as a stationary phase and a mobile phase consist mixture of $(65: 35 \% v / v)$. Water-acetonitrile used as diluents to $1 \mathrm{~L}$ portion add $5 \mathrm{~mL}$ heptaflurobutyric acid, $5 \mathrm{~mL}$ diethyl amine and $2.5 \mathrm{~mL}$ formic acid with flow rate $1 \mathrm{~mL} / \mathrm{min}$, the column outflow was scan at $273 \mathrm{~nm}$ [8].

Table 1: Dosage form, route of administration and recommended dose of BF.

\begin{tabular}{cccc}
\hline Dosage forms & Dose & $\begin{array}{c}\text { Route of } \\
\text { administration }\end{array}$ & \multicolumn{1}{c}{ Indication / dose } \\
\hline Tablet & $2.5 \mathrm{mg}$ & $\begin{array}{l}\text { Adult Hypertension } 5 \mathrm{mg} / \mathrm{day} \text { and maxim. } \\
20 \mathrm{mg} .\end{array}$ \\
Tablet & $1 \mathrm{mg}$ & $\begin{array}{l}\text { Patients with renal impairment: Not exceed } \\
10 \mathrm{mg} \text { once daily. }\end{array}$ \\
& $10 \mathrm{mg}$ & $\begin{array}{l}\text { Patients with severe liver impairment: No } \\
\text { dosage adjustment is required, however careful } \\
\text { monitoring is advised. }\end{array}$ \\
& & Oral & $\begin{array}{l}\text { The maximum recommended dose is } 10 \mathrm{mg} \\
\text { once daily. } \\
\text { Elderly: No dosage adjustment is normally } \\
\text { required. It is recommended to start with the } \\
\text { lowest possible dose. } \\
\text { Children: There is no experience with } \\
\text { bisoprolol in children, therefore its use cannot } \\
\text { be recommended for children. }\end{array}$ \\
\hline & $20 \mathrm{mg}$ &
\end{tabular}

\section{UV/VIS-SPECTROPHOTOMETRIC METHODS OF BF [9 -20]}

In article about nine UV-Spectrophotometric methods have been fixed for assurance of BFsingle and in combination of different dosage form. Also one spectroflurometric method has been accounted for determination of BF. The detailed summary spectrophotometer and spectroflurometer designating the basic principle, sample matrix, linearity and retention time in Table 2. 
Table 2: Spectrophotometric methods used for determination of BF alone and in combined dosage form.

\begin{tabular}{|c|c|c|c|c|c|c|c|}
\hline $\begin{array}{l}\text { Sr. } \\
\text { No }\end{array}$ & Drugs & Methods & $\begin{array}{c}\text { Detection } \\
\quad(\mathbf{n m})\end{array}$ & $\begin{array}{c}\text { Linearity } \\
(\mu \mathrm{g} / \mathrm{mL})\end{array}$ & $\begin{array}{c}\text { Correlation } \\
\text { coefficient } \\
\left(\mathbf{r}^{2}\right)\end{array}$ & $\begin{array}{c}\text { LOD and } \\
\text { LOQ } \\
(\mu \mathrm{g} / \mathrm{mL})\end{array}$ & Ref. \\
\hline 1 & $\begin{array}{l}\text { BIS with } \\
\text { bromocresol } \\
\text { green }\end{array}$ & Zero order & 402 & $7-80$ & 0.9998 & $\begin{array}{l}\text { LOD- } 1.78 \\
\text { LOQ- } 5.41\end{array}$ & 9 \\
\hline 2 & $\begin{array}{c}\text { BF and } \\
\text { HCT }\end{array}$ & First order & $223 \& 274$ & $\begin{array}{c}\text { BIS } 8 \text { - } 96 \\
\& \\
\text { HCT } 4 \text { - } 48\end{array}$ & $\begin{array}{c}0.999 \\
\& \\
0.998\end{array}$ & - & 10 \\
\hline 3 & $\mathrm{BF}$ & Zero order & 412 & $5-30$ & 0.9997 & $\begin{array}{l}\text { LOD- } 0.67 \\
\text { LOQ- } 2.23\end{array}$ & 11 \\
\hline 4 & $\begin{array}{l}\text { BIS using } \\
\text { methyl } \\
\text { orange }\end{array}$ & Zero order & 427 & $0.8-9$ & 0.9997 & $\begin{array}{l}\text { LOD- } 0.20 \\
\text { LOQ- } 0.66\end{array}$ & 12 \\
\hline 5 & $\begin{array}{c}\text { AMD B and } \\
\text { BF }\end{array}$ & Zero order & $356 \& 270$ & $\begin{array}{c}2-18 \\
\& \\
10-100\end{array}$ & $\begin{array}{l}0.9966 \\
\& \\
0.9941\end{array}$ & $\begin{array}{l}\text { LOD- } 0.4854 \\
\text { LOQ- } 0.2013\end{array}$ & 13 \\
\hline 6 & $\begin{array}{c}\text { BF by using } \\
\text { tropaeolin } \\
00\end{array}$ & Zero order & 412 & $5-30$ & 0.9995 & $\begin{array}{l}\text { LOD- } 0.67 \\
\text { LOQ- } 2.23\end{array}$ & 14 \\
\hline 7 & BF & Zero order & $\begin{array}{c}532 \text { and } \\
626\end{array}$ & $\begin{array}{c}100-500 \\
\& \\
50-300\end{array}$ & $\begin{array}{c}0.999 \\
\text { and } \\
0.998\end{array}$ & - & 15 \\
\hline 8 & $\begin{array}{c}\text { IRB and } \\
\text { BHF }\end{array}$ & Zero order & $\begin{array}{l}476 \text { and } \\
479 \\
\text { IRB and } \\
\text { BHF }\end{array}$ & $\begin{array}{c}20-90 \\
\text { and } \\
40-160\end{array}$ & $\begin{array}{l}0.9998 \\
\text { and } \\
0.9998\end{array}$ & $\begin{array}{c}\text { LOD- } 1.37 \\
\text { and } 3.98 \\
\text { and } \\
\text { LOQ- } 4.17 \\
\text { and } 12.06\end{array}$ & 16 \\
\hline 9 & $\begin{array}{c}\text { BF and } \\
\text { HCT }\end{array}$ & First order & $\begin{array}{c}\text { BF } 285.5 \\
\& \\
\text { HCT } 264.5\end{array}$ & $1.2-59$ & $\begin{array}{l}0.9997 \\
\& \\
0.9998\end{array}$ & $\begin{array}{l}\text { LOD- } 0.27 \text {, } \\
\text { LOQ- } 0.89 \\
\text { and } \\
\text { LOD- } 0.26 \text {, } \\
\text { LOQ- } 0.85\end{array}$ & 17 \\
\hline 10 & $\begin{array}{l}\text { BF with } \\
\text { BPB and } \\
\text { BCP }\end{array}$ & First order & BF 402 & $\begin{array}{c}\text { In BPB } \\
1.0-9.0 \\
\text { and } \\
\text { in BCP } \\
1.0-11.0\end{array}$ & $\begin{array}{c}\text { In BPB for } \\
\text { BIS } \\
0.9976 \\
\text { and BCP for } \\
\text { BIS } \\
0.9999\end{array}$ & $\begin{array}{c}\text { LOD in } \\
\text { BPB and in } \\
\text { BCP for BIS } \\
0.1791 \text { and } \\
0.5868 \text {, and } \\
\text { LOQ in BPB } \\
\text { and in BCP } \\
0.5964 \text { and } \\
1.9542\end{array}$ & 18 \\
\hline
\end{tabular}

An Insight on Analytical Profile on Bisoprolol Fumarate - A Selective Beta-1 Adrenoreceptor Blocker 


\begin{tabular}{|c|c|c|c|c|c|c|c|c|}
\hline $\begin{array}{l}\text { Dhandar, A.G. } \\
\text { Chaudhari, S.R. } \\
\text { Ganorkar, S.B. }\end{array}$ & $\begin{array}{l}\text { Sr. } \\
\text { No }\end{array}$ & Drugs & Methods & $\begin{array}{l}\text { Detection } \\
\quad(\mathbf{n m})\end{array}$ & $\begin{array}{l}\text { Linearity } \\
(\mu \mathrm{g} / \mathrm{mL})\end{array}$ & $\begin{array}{c}\text { Correlation } \\
\text { coefficient } \\
\left(\mathbf{r}^{2}\right)\end{array}$ & $\begin{array}{c}\text { LOD and } \\
\text { LOQ } \\
(\mu \mathrm{g} / \mathrm{mL})\end{array}$ & Ref. \\
\hline $\begin{array}{l}\text { Patil, A.S. } \\
\text { Surana, S.J. } \\
\text { Shirkhedkar, A.A. }\end{array}$ & 11 & $\begin{array}{c}\text { BF and } \\
\text { PRH }\end{array}$ & Zero order & $\begin{array}{c}\text { For both } \\
610\end{array}$ & $\begin{array}{l}2.0-16 \\
\text { and } \\
2.0-18\end{array}$ & $\begin{array}{l}0.9998 \\
\text { and } \\
0.9989\end{array}$ & $\begin{array}{l}\text { LOD- } 0.0678 \\
\text { LOQ- } 0.2257 \\
\text { and } \\
\text { LOD- } 0.0678 \\
\text { LOQ- } 0.2257\end{array}$ & 19 \\
\hline & 12 & $\begin{array}{c}\text { BF and } \\
\text { HCT }\end{array}$ & Zero order & $\begin{array}{l}224 \\
\text { and } \\
273\end{array}$ & $\begin{array}{c}3-21 \\
\text { and } \\
3-18\end{array}$ & $\begin{array}{c}0.9997 \\
\text { and } \\
0.9999\end{array}$ & - & 20 \\
\hline
\end{tabular}

\section{SPECTROFLUROMETRIC METHOD OF BF}

Hashem et al. (2016) reported IRB and BHF through spectroflurometric method. It is depend on charge transfer reaction between the designed drugs and 7-Chloro-4-nitrobenzen-2-oxa-1; 3-diazole NBD-CI. Dilution was prepared by using specific volume of NBD-CI $(0.1 \%, w / v)$. By using $5 \mathrm{~mL}$ with acetonitrile it get heated and after cooling the fusion of solution was attenuate to $10 \mathrm{~mL}$ with acetonitrile and methanol for IRB and BHF, respectively. The absorbance was recorded at 476 and 479 for IRB and BHF, at colored concentration respectively against the reagent blank treated similarly. The linearity was obeyed in the range of $2.5-8 \mu \mathrm{g} / \mathrm{mL}$ for IRB and $6-16 \mu \mathrm{g} / \mathrm{mL}$ for BHF. This method also gives detection limits of 0.18 and $0.39 \mu \mathrm{g} / \mathrm{mL}$ and a secondary quantification limit of 0.55 and $1.17 \mu \mathrm{g} / \mathrm{mL}$ for IRB and BHF. The statistical evaluation of the results with the results of reported methods reflected that there was no major differentiation [16].

\section{CHROMATOGRAPHIC SYNOPSIS}

\subsection{High-Performance Liquid-Chromatography [21-42]}

Distant from Pharmacopoeial methods many HPLC methods were accounted for assurance for BF in pharmaceutical formulation. The outlined of expressed HPLC methods specifically the mobile phase used for estimation, columns, wavelength, correlation coefficient and linearity range is shown in the Table 3.

Table 3: HPLC methods of analysis for BF.

\begin{tabular}{|c|c|c|c|c|c|}
\hline $\begin{array}{l}\text { Sr. } \\
\text { No }\end{array}$ & $\begin{array}{c}\text { Name of } \\
\text { drug }\end{array}$ & Columns & Mobile phase system & Discussion & Ref \\
\hline 1. & $\begin{array}{c}\text { BF and } \\
\text { HCT } \\
\text { (tablet) }\end{array}$ & $\begin{array}{c}\text { Inertsil ODS } \\
3 \mathrm{~V}\end{array}$ & $\begin{array}{l}0.1 \mathrm{M} \text { potassium } \\
\text { dihydrogen phosphate } \\
\text { buffer and acetonitrile } \\
\text { in the ratio of }(70: 30 \\
\% \mathrm{v} / \mathrm{v})\end{array}$ & $\begin{array}{l}\text { Detection of } \mathrm{BF} \text { and } \mathrm{HCT} \\
\text { was carried out at } 228 \mathrm{~nm} \text { and } \\
\text { linearity obeyed in the range } \\
\text { of } 2.5-50 \mu \mathrm{g} / \mathrm{mL} \text { and } 6.25- \\
125 \mu \mathrm{g} / \mathrm{mL} \text {. Retention time } \\
\text { for } \mathrm{BF} \text { and } \mathrm{HCT} \text { was found to } \\
\text { be } 5.058 \mathrm{~min} \text { and } 2.783 \mathrm{~min} \text {. }\end{array}$ & 21 \\
\hline
\end{tabular}




\begin{tabular}{|c|c|c|c|c|c|}
\hline $\begin{array}{l}\text { Sr. } \\
\text { No }\end{array}$ & $\begin{array}{c}\text { Name of } \\
\text { drug }\end{array}$ & Columns & Mobile phase system & Discussion & Ref \\
\hline 2. & $\begin{array}{l}\text { BF and } \\
\text { HCT } \\
\text { (tablet) }\end{array}$ & $\begin{array}{l}\text { RP Zorbax } \\
\text { Eclipse } \\
\text { XDB-C18 }\end{array}$ & $\begin{array}{l}\text { Acetonitrile-water } \\
(25: 75 \% \mathrm{v} / \mathrm{v}) \\
\text { Containing } 15 \mathrm{mM} \\
\text { phosphoric acid }\end{array}$ & $\begin{array}{l}\text { Detection of } \mathrm{BF} \text { and } \mathrm{HCT} \\
\text { was carried out at } 225 \mathrm{~nm} \text {. } \\
\text { Linearity range for } \mathrm{BF} \text { and } \\
\mathrm{HCT} 0.50-12.00 \text { and } 0.20- \\
8.00 \mu \mathrm{g} / \mathrm{mL} \text { Correlation } \\
\text { coefficient for BF and HCT } \\
0.999 \text { and } 0.999 \text {. Retention } \\
\text { time for BF and HCT } 5.058 \\
\text { min and } 2.783 \text { min. }\end{array}$ & 22 \\
\hline 3. & $\begin{array}{l}\text { BF and } \\
\text { AMD } \\
\text { (tablet) }\end{array}$ & Luna C18-2 & $\begin{array}{l}25 \mathrm{mM} \text { ammonium } \\
\text { acetate adjusted to } \mathrm{pH} \\
5.0 \text { and methanol } \\
(65: 35 \% \mathrm{v} / \mathrm{v})\end{array}$ & $\begin{array}{l}\text { Detection of BF and AMD } \\
\text { was carried out at } 230 \mathrm{~nm} \text {. } \\
\text { Linearity was established } \\
\text { in the range of } 8-33 \mu \mathrm{g} / \mathrm{mL} \text {. } \\
\text { Retention time was } 1.45 \mathrm{~min} \\
\text { and } 3.91 \text { min for } \mathrm{BF} \text { and } \\
\text { AMD. } \\
\text { Correlation Coefficient for } \\
\text { BIS } 0.999 \text { and AMD } 0.999 \text {. }\end{array}$ & 23 \\
\hline 4 & $\begin{array}{c}\text { BF } \\
\text { (tablet) }\end{array}$ & Hypersil ODS & $\begin{array}{l}\text { mixture of buffer and } \\
\text { acetonitrile in the ratio } \\
\text { of }(700: 300 \% v / v)\end{array}$ & $\begin{array}{l}\text { Detection of BF was carried } \\
\text { out at } 208 \mathrm{~nm} \text {. Retention } \\
\text { time of } 3.146 \mathrm{~min} \text {. Linearity } \\
5.00-17.5 \mu \mathrm{g} / \mathrm{mL} \text { for BF. } \\
\text { Correlation Coefficient } \\
0.998 \text {. }\end{array}$ & 24 \\
\hline 5. & $\begin{array}{l}\text { BIS F } \\
\text { (tablet) }\end{array}$ & $\begin{array}{l}\text { prontosil, } \\
\text { chromo bond }\end{array}$ & $\begin{array}{l}\text { buffer }(\mathrm{pH} 5.6) \text { and } \\
\text { acetonitrile in the ratio } \\
\text { of }(750: 250 \% \mathrm{v} / \mathrm{v})\end{array}$ & $\begin{array}{l}\text { Detection of BIS F was } \\
\text { carried out at } 226 \mathrm{~nm} \text {. } \\
\text { Linearity at } 6 \text { different levels } \\
\text { from } 25 \mu \mathrm{g} / \mathrm{mL} \text { to } 100 \mu \mathrm{g} / \mathrm{mL} \text {. } \\
\text { The retention time of BIS } \\
\mathrm{F} \text { was found to be } 9.15 \mathrm{~min} \text {. } \\
\text { Correlation coefficient } \\
0.999917 \text {. }\end{array}$ & 25 \\
\hline 6. & $\begin{array}{c}\text { BIS F and } \\
\text { AMD B } \\
\text { (tablet) }\end{array}$ & C18Intersil & $\begin{array}{l}\text { Methanol: } \\
\text { Acetonitrile: } 50 \mathrm{mM} \\
\text { Potassium dihydrogen } \\
\text { phosphater buffer } \\
\text { KH2PO4 (25:30:45\% } \\
v / v)\end{array}$ & $\begin{array}{l}\text { Detection of BIS F and AMD } \\
\text { B was carried out at } 267 \mathrm{~nm} \text {. } \\
\text { Correlation Coefficient For } \\
\text { BIS } 0.998 \text { and AMD besylate } \\
0.999 \text {. }\end{array}$ & 26 \\
\hline 7. & $\begin{array}{l}\text { BF and } \\
\text { HCT } \\
\text { (tab) }\end{array}$ & $\begin{array}{l}\text { C18 column } \\
\text { Kromasil 100- } \\
5 \text { C18 column }\end{array}$ & $\begin{array}{l}\text { acetonitrile-0.01 } \mathrm{M} \\
\mathrm{KH} 2 \mathrm{PO} 4(40: 60 \% \quad v / v \\
\text { and } \mathrm{pH} 3.5)\end{array}$ & $\begin{array}{l}\text { Detection of } \mathrm{BF} \text { and } \mathrm{HCT} \\
\text { was carried out at } 232 \mathrm{~nm} \text {. } \\
\text { Linearity: }-1-7 \text { and } 2.5- \\
17.5 \mu \mathrm{g} / \mathrm{mL} \text { for } \mathrm{BF} \text { and } \mathrm{HCT} \text {. } \\
\text { Amplitudes at } 228.4 \text { and } \\
283 \mathrm{~nm} \text { of } \mathrm{BF} \text { and HCT. } \\
\text { Correlation Coefficient For } \\
\mathrm{BF} 0.9999 \text { and for HCT } \\
0.9999 \text {. Retention Time:- } \\
\mathrm{BF} \text { and HCT were eluted at } \\
3.38 \pm 0.04 \text { and } 4.03 \pm 0.02 \text { min. }\end{array}$ & 27 \\
\hline
\end{tabular}


Dhandar, A.G.

Chaudhari, S.R.

Ganorkar, S.B.

Patil, A.S.

Surana, S.J.

Shirkhedkar, A.A.

\begin{tabular}{|c|c|c|c|c|c|}
\hline $\begin{array}{l}\text { Sr. } \\
\text { No }\end{array}$ & $\begin{array}{l}\text { Name of } \\
\text { drug }\end{array}$ & Columns & Mobile phase system & Discussion & Ref \\
\hline 8. & $\begin{array}{c}\text { BF } \\
\text { enantiomer }\end{array}$ & $\begin{array}{l}\text { Chiralcel OD } \\
\text { column }\end{array}$ & $\begin{array}{l}\text { methanolglacial acetic } \\
\text { acid-triethylamine, } \\
(100: 0.020: 0.025 \% \\
v / v / v)\end{array}$ & $\begin{array}{l}\text { Detection of BF was carried } \\
\text { out at excitation/emission } \\
275 / 305 \mathrm{~nm} \text {. Linearity was } \\
\text { found to be } 5-250 \mathrm{ng} / \mathrm{mL} \text {. } \\
\text { Correlation coefficient of } \\
0.999 \text {. }\end{array}$ & 28 \\
\hline
\end{tabular}

9. BF and C18 column Acetonitrile and Detection of BF and HCT

HCT Kromasil phosphate buffer was carried out at 228. For

(tablet) $\quad(40: 60 \% v / v, \mathrm{pH} 3)$ both $\mathrm{BF}$ and HCT linearity

was found to be $20-100 \mu \mathrm{g} /$

$\mathrm{mL}$. The retention time of

$\mathrm{BF}$ and $\mathrm{HCT}$ were $3.3 \mathrm{~min}$

and $6.25 \mathrm{~min}$. correlation

coefficient 0.998 and 0.999 .

10. BF C18 column Phosphate buffer ( $\mathrm{pH}$ Detection of BF was carried Kromasil 100- 3.5) and acetonitrile out at $225 \mathrm{~nm}$. Linearity

$5 \mathrm{C} 18 \quad(70: 30 \% v / v) 1 \mathrm{ml} / \mathrm{min}$ is $5-90 \mu \mathrm{g} / \mathrm{mL}$. Retention time 1.158 min.Correlation coefficient 0.9998 and regression coefficient 0.9996 .

11. BF Eclipse XDB Water / methanol / Detection of BF was carried (tablet) C18 acetonitrile in a ratio out at $225 \mathrm{~nm}$. Two areas of of $(50: 30: 20 \% \mathrm{v} / \mathrm{v} / \mathrm{v}) \quad$ linearity in the range of 0.8 $-80 \mathrm{~g} / \mathrm{mL}$ and $80-1000 \mathrm{~g} /$ ML.

Correlation coefficient 0.999 and intercept 0.4953 with a regression coefficient $\mathrm{R} 2=$ 0.999. $\mathrm{LOD}=1.3 \mathrm{~g} / \mathrm{mL}$ LOQ $=3.98 \mathrm{~g} / \mathrm{mL}$.

12. BF and HCT and impurities (tablet)

13. BF with potential impurity
BDS Hypersil [acetonitrile-

C8 column ammonium

dihydrogen

phosphate/

orthophosphoric

acid buffer solution

$(80: 20 \% v / v)$

LiChrosorb RP-18

Detection of BF and HCT was carried out at $220 \mathrm{~nm}$. Linearity $\quad 1.50-46.20$ and 3.80-114.00 $\quad \mu \mathrm{g} / \mathrm{mL}$. Correlation coefficient 0.9998 and 0.9998. Recovery: 98$102 \%$ for active ingredients (B for HCT), 90-110\% for impurities (A, L, K For BF impurity). Acetonitrile- $0.050 \mathrm{M}$ Detection of $\mathrm{BF}$ and $\mathrm{HCT}$
ammonium phosphate was carried out at $226 \mathrm{~nm}$. buffer $(4: 6 \% v / v)$. Regression coefficient of the linearity test was 0.9996 . 


\begin{tabular}{|c|c|c|c|c|c|}
\hline $\begin{array}{l}\text { Sr. } \\
\text { No }\end{array}$ & $\begin{array}{c}\text { Name of } \\
\text { drug }\end{array}$ & Columns & Mobile phase system & Discussion & Ref \\
\hline 14. & $\begin{array}{l}\text { BF with } \\
\text { HCT }\end{array}$ & Zodiacsil-C18 & $\begin{array}{l}\text { buffer solution }(\mathrm{pH} \\
3.60) \text { containing } 5 \mathrm{mM} \\
\text { monobasic potassium } \\
\text { phosphate in milliQ- } \\
\text { water. Mobile phase B } \\
\text { consists of a mixture } \\
\text { of acetonitrile and } \\
\text { methanol in the ratio } \\
(80: 20 \% \mathrm{v} / \mathrm{v})\end{array}$ & $\begin{array}{l}\text { Detection of } \mathrm{BF} \text { and } \mathrm{HCT} \\
\text { was carried out at } 226 \mathrm{~nm} \text {. } \\
\text { Correlation coefficient } \\
\text { obtained was } 0.999 \text {. Stability } \\
\text { indicating in the range of } \\
\text { LOQ to } 150 \% \text {. The retention } \\
\text { times was studied between } \pm \\
0.2 \text { units. }\end{array}$ & 34 \\
\hline 15. & $\begin{array}{l}\text { BF } \\
\text { separated } \\
\text { by chiral } \\
\text { stationary } \\
\text { column }\end{array}$ & Chiralpak IB & $\begin{array}{l}\text { n-hexane/ethanol } \\
95 / 5 \% \quad v / v), \quad 0.2 \% \\
\text { DEA) }\end{array}$ & $\begin{array}{l}\text { Detection of BIS was carried } \\
\text { out at } 223 \mathrm{~nm} \text {. Correlation } \\
\text { Coefficient was found to be } \\
0.8635 \text {. } \\
\text { Retention Time was over } 100 \\
\text { min. }\end{array}$ & 35 \\
\hline 16. & $\begin{array}{l}\text { BF with } \\
\text { selected } \\
\text { excepient }\end{array}$ & $\begin{array}{l}\text { Hypersil BDS } \\
\text { C18 }\end{array}$ & $\begin{array}{l}\text { acetonitrile- } \\
\text { potassium dihydrogen } \\
\text { phosphate buffer }(\mathrm{pH} \\
3.0 \text {, adjusted with } \\
\text { orthophosphoric acid; } \\
20 \mathrm{mM})(50: 50 \% \mathrm{v} / \mathrm{v})\end{array}$ & $\begin{array}{l}\text { Detection of } \mathrm{BF} \text { was } \\
\text { carried out at } 222 \mathrm{~nm} \text {. } \\
\text { Linearity in the range of } \\
10-100 \mu \mathrm{g} / \mathrm{mL} \text {.Correlation } \\
\text { Coefficient:- } 0.999 \text {. } \\
\text { LOD and LOQ values were } \\
\text { found to be } 0.03 \text { and } 0.1 \mathrm{~g} / \mathrm{mL} \text {. } \\
\text { Retention Time: }-4.00 \mathrm{~min} \text {. }\end{array}$ & 36 \\
\hline 17. & $\begin{array}{l}\mathrm{BF} \\
\mathrm{Tab}\end{array}$ & $\begin{array}{l}\text { Chromolith } \\
\text { RP18-e }\end{array}$ & $\begin{array}{l}\text { phosphate buffer } \\
\text { (pH3.5): acetonitrile } \\
(77.5: 22.5 \% v / v)\end{array}$ & $\begin{array}{l}\text { Detection of BF was carried } \\
\text { out at excitation/emission } \\
232 / 320 \mathrm{~nm} \text {. Linearity range } \\
\text { is } 3 \text { to } 200 \mathrm{ng} / \mathrm{mL} \text {, correlation } \\
\text { coefficient of } 0.9998 \text { The } \\
\text { LOQ was } 3 \mathrm{ng} / \mathrm{mL} \text {. Retention } \\
\text { Time was detected } 4.5 \mathrm{~min} \\
\text { and } 7.24 \mathrm{~min} \text {. }\end{array}$ & 37 \\
\hline 18. & $\mathrm{BF}$ & $\begin{array}{l}\text { Zorbax SB- } \\
\text { C18 Solvent } \\
\text { Saver Plus }\end{array}$ & $\begin{array}{l}0.1 \% \text { formic acid } \\
\text { solution - acetonitrile } \\
(50-50 \% \mathrm{v} / \mathrm{v})\end{array}$ & $\begin{array}{l}\text { Detection of BF was carried } \\
\text { out at } 226 \mathrm{~nm} \text {. Linearity in the } \\
\text { range of } 1 \mathrm{ng} / \mathrm{Ml} \text { and } 100 \mathrm{ng} / \\
\mathrm{mL} \text {. Correlation Coefficient } \\
\text { of } 0.998599, \\
\text { LOQ is } 1 \mathrm{ng} / \mathrm{mL} \text {. Retention } \\
\text { Time is } 1.7 \mathrm{~min} \text { and } 1.9 \text { min. }\end{array}$ & 38 \\
\hline 19. & $\mathrm{BF}$ & $\begin{array}{l}\text { Kromasil } \\
\text { C18 column }\end{array}$ & $\begin{array}{l}\text { methanol and } \\
0.05 \% \text { phosphoric } \\
\text { acid }(40: 60 \% \mathrm{v} / \mathrm{v})\end{array}$ & $\begin{array}{l}\text { Detection of BF was carried } \\
\text { out at exci. /emmi } 275 / 305 \\
\mathrm{~nm} \text {. Linearity in the range of } \\
10-100 \mathrm{ng} / \mathrm{mL} \text {. Correlation } \\
\text { Coefficient: - } 0.994 \text {. LOD: } 3 \\
\mathrm{ng} / \mathrm{mL} \text {. LOQ: } 10 \mathrm{ng} / \mathrm{mL} \text {. }\end{array}$ & 39 \\
\hline
\end{tabular}


Dhandar, A.G.

Chaudhari, S.R.

Ganorkar, S.B.

Patil, A.S.

Surana, S.J.

Shirkhedkar, A.A.

\begin{tabular}{|c|c|c|c|c|c|}
\hline $\begin{array}{l}\text { Sr. } \\
\text { No }\end{array}$ & $\begin{array}{c}\text { Name of } \\
\text { drug }\end{array}$ & Columns & Mobile phase system & Discussion & Ref \\
\hline 20. & $\begin{array}{l}\text { BF film } \\
\text { coated tab }\end{array}$ & $\begin{array}{c}\text { Nucleosil } \\
\text { 100-5 C18 } \\
\text { HD }\end{array}$ & $\begin{array}{l}\text { water and formic acid } \\
\text { as solvent } \mathrm{A} \text { in the } \\
\text { ratio }(99 \%: 1 \%(\mathrm{v} / \mathrm{v}) \\
\text { and acetonitrile and } \\
\text { formic acid as solvent } \\
\mathrm{B} \text { in the ratio }(99 \%: \\
1 \% \mathrm{v} / \mathrm{v})\end{array}$ & $\begin{array}{l}\text { Detection of } \mathrm{BF} \text { was carried } \\
\text { out at } 225 \mathrm{~nm} \text {. The retention } \\
\text { times are } 16.2 \mathrm{~min} .\end{array}$ & 40 \\
\hline 21. & $\begin{array}{c}\mathrm{BF} \text { and } \\
\mathrm{HCT}\end{array}$ & $\begin{array}{l}\text { YMC Pack } \\
\text { Pro C18 } \\
\text { column }\end{array}$ & $\begin{array}{l}0.1 \% \text { orthophosphoric } \\
\text { acid and acetonitrile } \\
(55: 45 \% \mathrm{v} / \mathrm{v})\end{array}$ & $\begin{array}{l}\text { Detection of BF and } \mathrm{HCT} \\
\text { was carried out at } 259 \mathrm{~nm} \text {. } \\
\text { Linearity range of } 40-120 \mu \mathrm{g} / \\
\mathrm{mL}(\mathrm{BF}) \text { and } 50-150 \mu \mathrm{g} / \mathrm{mL} \\
(\mathrm{HCT}) \text {. } \\
\text { Correlation Coefficient :- } \\
0.9999 \\
\mathrm{LOQ} \text { was } 0.398 \text { and } 0.385 \mu \mathrm{g} / \\
\mathrm{mL} \text { for BIS and HCT. LOD } \\
(\mu \mathrm{g} / \mathrm{ml}) 0.398 \text { and } 0.385 \text {. }\end{array}$ & 41 \\
\hline 22. & $\begin{array}{l}\text { BF and } \\
\text { HCT }\end{array}$ & Zodiac C18 & $\begin{array}{l}\text { phosphate buffer and } \\
\text { acetonitrile in the ratio } \\
\text { of }(80: 20 \% \mathrm{v} / \mathrm{v})\end{array}$ & $\begin{array}{l}\text { Detection of } \mathrm{BF} \text { and } \mathrm{HCT} \\
\text { was carried out at } 208 \mathrm{~nm} \text {. } \\
\text { Linearity was obeyed in } \\
\text { the range } 2.5-75 \mu \mathrm{g} / \mathrm{ml} \text { and } \\
3-90 \mu \mathrm{g} / \mathrm{ml} \text { of } \mathrm{BF} \text { and } \mathrm{HCT} \text {. } \\
\text { The retention time of BF and } \\
\mathrm{HCT} \text { was found to be } 2.253 \\
\text { min and } 4.425 \mathrm{~min} \text {. LOD and } \\
\mathrm{LOQ} \text { for BF } 2 \mu \mathrm{g} / \mathrm{ml} \text { and } 6 \mu \mathrm{g} / \\
\mathrm{ml} \text { and for } \mathrm{HCT} 0.9 \mu \mathrm{g} / \mathrm{ml} \\
\text { and } 1.8 \mu \mathrm{g} / \mathrm{mL} \text {. }\end{array}$ & 42 \\
\hline
\end{tabular}

\subsection{High- Performance -Thin- Layer Chromatography [43-45]}

About 3 HPTLC methods have been studied for simulation determination of $\mathrm{BF}$ with $\mathrm{HCT}$ and camphorsulphonic acid in different pharmaceutical dosage form.

Emanual M Patelia et al. (2013) investigated specific and precise method for quantitative estimation of BFand HCT in pharmaceutical dosage form. The separation of the BF and HCT was conceded on aluminum plate precoated with silica gel $60 \mathrm{~F}_{254}$ using mobile phase chloroform: ethanol: glacial acetic acid (5:1.5:0.2 v/v/v).The $\mathrm{R} f$ value was found to be 0.62 and 0.40 for $\mathrm{BF}$ and HCT, respectively when the densitometry quantification was performed maximum at $225 \mathrm{~nm}$. For analysis of BF and HCT, linearity was studied in the range of 200 $1200 \mathrm{ng} / \mathrm{b}$ and and 100 - $800 \mathrm{ng} / \mathrm{band}$, respectively. Accurateness of the method was studied by \% recovery and found to be $100.02 \pm 1.14 \%$ for BF and $99.91 \pm$ $0.96 \%$ for HCT [43]. Similarly; Rao et al. (2013) also developed and validated an 
effortlessmanner for determination of BF and HCT. The separation was achieved on aluminum plates percolated silica gel $60 \mathrm{~F}_{254}$ using mixture of ethyl acetate: methanol: ammonia 10:0.5:0.5 v/v/v) as mobile phase with $\mathrm{R} f$ of BF and HCT were 0.60 and 0.38 , in that order and detection was monitored at $225 \mathrm{~nm}$. For estimation of drugs, the linearity experiment was performed in the range of 150$900 \mathrm{ng} / \mathrm{spot}$ for BF and 100-600 ng/spot for HCT. Linear regression for BF and HCT was 0.999 [44]. The established methods were validated for correctness, robustness and specificity as per ICH guidelines.

Patel et al. (2011) reported an enantiomer separation of BF by TLC and HPTLC by means of (+)-10-camphorsulphonic acid as a chiral selector. Chromatographic separation of $\mathrm{BF}$ was performed with optically pure (+)-10-camphorsulphonic acid as a chiral selector. The mobile phase set for separation was triethyl amine-methanol-1-pentanol $(0.14: 9.9: 0.18, \% v / v / v)$. For TLC detection was executed at UV-chamber at short wavelength $254 \mathrm{~nm}$ and for HPTLC densitometry detection performed at $224 \mathrm{~nm}$. The calibration ranges for both the isomers were $5-30 \mu \mathrm{g} / \mathrm{mL}$ [45].

\section{STABILITY- INDICATING METHODS (SIM) FOR ESTIMATION OF BF [46-51]}

With reference four stability indicating methods studied accordingly for persistence of $\mathrm{BF}$ in bulk substance and pharmaceutical dosage form implementing several analytical techniques. The reported stability indicating methods for BF illustrating dosage form, column, mobile phase and linearity and retention factor presented in [Table: 4].

Table 4: Stability indicating methods of BF by HPLC and UPLC.

\begin{tabular}{|c|c|c|c|c|c|c|c|}
\hline $\begin{array}{l}\text { Sr. } \\
\text { No }\end{array}$ & Drugs & Formulation & Column & $\begin{array}{l}\text { Mobile Phase } \\
\text { System }\end{array}$ & Detection & Discussion & Ref \\
\hline 1 & $\mathrm{BF}$ & Tablet & $\begin{array}{c}\text { Chromo } \\
\text { band C18 }\end{array}$ & $\begin{array}{l}\text { Buffer/ } \\
\text { Acetonitrile } \\
(75: 25 \% v / v, \mathrm{pH} \\
5.6)\end{array}$ & $226 \mathrm{~nm}$ & $\begin{array}{l}\text { Linearity was found to } \\
\text { be } 25 \text { and } 100 \mu \mathrm{g} / \mathrm{mL} \text {. } \\
\text { Correlation Coefficient: } \\
-0.9998 \text {. } \\
\text { Retention Time:- } 9.5\end{array}$ & 46 \\
\hline 2 & $\begin{array}{c}\text { BF } \\
\text { and } \\
\text { AMD }\end{array}$ & Aq.solution & $\mathrm{C} 18$ & $\begin{array}{l}\text { Acetonitrile- } \\
\text { water solution } \\
\text { of } 10 \mathrm{mM} \\
\text { ammonium } \\
\text { acetate } \\
(92: 8 \% \mathrm{v} / \mathrm{v})\end{array}$ & $230 \mathrm{~nm}$ & $\begin{array}{l}\text { Retention Time is } 4.042 \\
\text { min. }\end{array}$ & 47 \\
\hline
\end{tabular}

An Insight on Analytical Profile on Bisoprolol Fumarate - A Selective Beta-1 Adrenoreceptor Blocker 
Dhandar, A.G.

Chaudhari, S.R.

Ganorkar, S.B.

Patil, A.S.

Surana, S.J.

Shirkhedkar, A.A.

\begin{tabular}{ccccl}
\hline $\begin{array}{l}\text { Sr. } \\
\text { No }\end{array}$ & Drugs & Formulation & Column & $\begin{array}{l}\text { Mobile Phase } \\
\text { System }\end{array}$ \\
\hline 3 & BF & Tablet & YMC Pack & $0.1 \%$ \\
& and & & Pro C18 & $\begin{array}{l}\text { Orthophosphoric } \\
\text { acid and } \\
\text { acetonitrile } \\
\end{array}$ \\
HCT & & & $(55: 45 \% v / v)$
\end{tabular}

4 BF

Tablet

HP1200

Acetonitrilewater solution (10 $\mathrm{mM}$ ammoniumacetate, $\mathrm{pH}$ 4.0, adjusted with concentrated acetic acid) at a ratio of ( $92: 8 \%$ $v / v)$

$\begin{array}{lll}5 & \text { BF } & \text { Tablet } \\ \text { and } & \\ \text { HCT } & \end{array}$

6

$\begin{array}{cccl}\text { BF } & \text { Tablet } & \text { Acquity } & \text { Water : } \\ \text { and } & & \text { UPLC } & \text { acetonitrile } \\ \text { HCT } & & \text { BEH C18 } & (50: 50 \% v / v)\end{array}$

\section{Detection Discussion}

Ref

$259 \mathrm{~nm}$ Linearity for both BF

and HCT: - 40-120

and $50-150 \quad \mu \mathrm{g} / \mathrm{mL}$ .Correlation Coefficient was found to be 0.9999 . Retention Times 3.688 min and $5.824 \mathrm{~min}$.

$230 \mathrm{~nm} \quad \mathrm{R}$-value for zero-order reaction had the highest value 0.9747 .

$226 \mathrm{~nm}$

Correlation Coefficient was found to be 0.999 .

A retention time was studied between \pm 0.2 units.

\section{0} consisting of a buffer solution (pH 3.60) containing 5 $\mathrm{mM}$ monobasic potassium phosphate in milliQ-water. Mobile phase B consists of a mixture of acetonitrile and methanol in the ratio $80: 20 \% v / v$ )
$225 \mathrm{~nm} \quad$ Linearity in the range of 51 $0.5-250 \mu \mathrm{g} / \mathrm{mL}$ for $\mathrm{BF}$ and $0.5-150 \mu \mathrm{g} / \mathrm{mL}$.
Correlation Coefficient (r) was found to be 0.999. For human urine linear in the range between 0.5 and $10 \mu \mathrm{g} /$ $\mathrm{mL}$ for HCT and 0.5-30 $\mu \mathrm{g} / \mathrm{mL}$ for BF. LOD and LOQ $0.07-0.21 \mu \mathrm{g} / \mathrm{mL}$ ; and $0.01-0.03 \mu \mathrm{g} / \mathrm{mL}$ for $\mathrm{BF}$ and $\mathrm{HCT}$




\section{CAPILLARY ZONE ELECTROPHORESIS METHOD [52-55]}

Laszlo Gagyi et al. (2006) established a effortless capillary electrophoresis method for estimation of various stereoselective $\beta 1$-blockers and H1antihistamines by human serum transferrin. For the chiral separation of stereoselective $\beta 1$-blockers and $\mathrm{H} 1$ - antihistamines, pseudostationary protein zone was used. In that developed method about 15 compounds were screened and nearly all of them illustrate longer migration time, showed a communication with transferrin. Stereoselective interaction was observed only for five $\beta 1$ blockers(CEL, TALINO, MEPIN, BOPIN, and OXPRE) and for one H1antihistamine (bromopheniramine). A polyacrylamide-coated (3\%, noncrosslinked)capillary (34 cm effective length $650 \mathrm{~mm}$ id) was carried out[52].

Hong-Bing Duanetal. (2015) described a new routine estimation of METO TandBF. In that developed method, capillary electrophoresis fixed with tris (2,2'-bipyridyl)-ruthenium (II) electrochemiluminescence for the estimationas well asillustrates relationship between the METO T and BF and human serum albumin. There are different parameters were selected for optimization of CZE separation; because they affect the CZE separation and ECL detection, the optimized parameters like $\mathrm{pH}$, amount of running buffer, detachment voltage and potential exposures. Under enhanced condition METO $\mathrm{T}$ and $\mathrm{BF}$ were well separated and identified within $10 \mathrm{~min}$ [53].

Jingwu Wang et al. (2008) illustrate daspeedy, selective, and responsive capillary zone electrophoresis (CZE) attached through tris (2,2-bipyridyl) ruthenium(II)-based end-column electrogenerated chemiluminescence (ECL) was utilized to estimate $\mathrm{BF}$ in bulk and tablets subsequent to its separation from METO. Tetrahydrofuran were used as an additive in the running buffer to receive the absolute ECL peak of BF. It react with tris (2, 2-bipyridyl) ruthenium (II) ECL system. Under the advanced experimental situation, BF was separated successfully and efficiently from METO and other co-existed materials in tablets and urine samples [54].

Laszlo Gagyiet al. (2008) reported the stereoselective detection of $\beta$-blockers by cyclodextrins within capillary zone electrophoresis. This category of medicinal agent was resolved by cardiovascular system disease and its derivativechiral aryloxy-propanolamine. In general, the $S(-)$ enantiomer aremore active than the $\mathrm{R}(+)$ enantiomer. Study understand the appliance of a choice of cyclodextrin derivatives, hydroxypropyl- $\beta$-cyclodextrins, at randommethylated $\beta$-cyclodextrin, sulphated $\beta$-cyclodextrin and sulphated $\alpha$-cyclodextrins for the stereoselective examination of $\beta$-blockers. Separation was obtained for BOPI, CARV, MEPI, PIND and ALPR, while only partial separation was observed for SOT, PROP, OXPRE, ATEN, BIS, BUPRA and METO [55].
An Insight on Analytical Profile on Bisoprolol Fumarate - A Selective Beta-1 Adrenoreceptor Blocker 
Dhandar, A.G.

Chaudhari, S.R.

Ganorkar, S.B.

Patil, A.S.

Surana, S.J.

Shirkhedkar, A.A.

\section{ACCOUNT ON BIO-ANALYTICAL METHOD FOR DETERMINATION OF BF [56-67]}

Bioanalytical methods are used for the quantitation of drugs and their metabolites and biological molecule in unnatural location or concentration) and biotic (macromolecule, large molecule drugs and metabolites) in organic systems[56]. Literature survey revealed that LC-MS/MS and HPLC and are predominantly used for the bioanalysis of BF. In Bioanalytical method validation sample is extracted from plasma with help of extraction techniques such as protein precipitation, liquid-liquid extraction and solid phase extraction techniques. In most of methods methanol was used as solvent for extraction of BF in biological fluids. Bioanalytical methods for determination of BF are summarized in [Table: 5 ].

Table 5: Bioanalytical determination of BF.

\begin{tabular}{|c|c|c|c|c|c|}
\hline $\begin{array}{l}\text { Sr. } \\
\text { No. }\end{array}$ & Drugs & $\begin{array}{l}\text { Biological } \\
\text { fluid }\end{array}$ & $\begin{array}{c}\text { Chromatographic } \\
\text { conditions }\end{array}$ & Discussion & Ref \\
\hline 1 & $\mathrm{BF}$ & $\begin{array}{l}\text { Human } \\
\text { plasma }\end{array}$ & $\begin{array}{l}\text { RP-C18 column } \\
\text { (Inertsil, } 4 \mathrm{~mm}, 150 \mathrm{x} \\
4.6 \mathrm{~mm}), \\
\text { Methanol: water } \\
(70: 30, \% \mathrm{v} / \mathrm{v})\end{array}$ & $\begin{array}{l}\text { Sevgi Tatar Uluet al. Described } \\
\text { derivatization of BF with 4-chloro- } \\
\text { 7-nitro-2, 1, 3-benzoxadiazole in borate } \\
\text { buffer at } \mathrm{pH} 9.5 \text { to yield a fluorescent } \\
\text { product. Plasma samples (BF and IS) } \\
\text { were extracted employing a liquid-liquid } \\
\text { extraction method. Ephedrine was used } \\
\text { as internal standard. Linearity obeyed in } \\
\text { the range of } 10-2,000 \mathrm{ng} / \mathrm{mL} \text { Retention } \\
\text { times was approximately } 4.79 \text { min for BF } \\
\text { and } 3.46 \text { min for IS. }\end{array}$ & 57 \\
\hline 2 & $\begin{array}{l}\text { AMD and } \\
\text { BF }\end{array}$ & Rat plasma & $\begin{array}{l}\text { Diamonsil C18 } \\
\text { column }(50 \mathrm{~mm} \times 4.6 \\
\mathrm{mm}, 5 \mu \mathrm{m}) \text {, } \\
\text { Methanol: water: } \\
\text { formic acid } \\
(75: 25: 0.01, \% v / v / v)\end{array}$ & $\begin{array}{l}\text { HuichaoChanget al. Illustrated a sensitive, } \\
\text { specific liquid chromatography-tandem } \\
\text { mass spectrometry method for quantitative } \\
\text { determination of AMD and BF. The } \\
\text { analytes and IS were isolated plasma } \\
\text { samples by liquid-liquid extraction. } \\
\text { Linearity was followed in the range of } \\
0.2-50 \mathrm{ng} / \mathrm{mL} \text { and correlation coefficient } \\
0.9961 \mathrm{for} \text { both BF and AMD. Retention } \\
\text { time } 2.12,1.96 \text { and } 1.89 \text { min for both. }\end{array}$ & 58 \\
\hline 3 & $\mathrm{BF}$ & $\begin{array}{l}\text { Human } \\
\text { plasma }\end{array}$ & $\begin{array}{l}\text { RP-C18 Column }(3 \times \\
100 \mathrm{~mm}, 3.5 \mu \mathrm{m}), \\
0.1 \% \text { formic acid } \\
\text { solution }- \text { acetonitrile } \\
(50-50 \% \mathrm{v} / \mathrm{v})\end{array}$ & $\begin{array}{l}\text { Gabriela Peste } \text { et al. Developed specific } \\
\text { liquid chromatography-tandem mass } \\
\text { spectrometrymethoddetermination of BF . } \\
\text { The analytes extracted using liquid-liquid } \\
\text { extraction method and metoprolol was IS. } \\
\text { Linearity obeyed in the range of } 1 \mathrm{ng} / \mathrm{mL} \\
\text { and } 100 \mathrm{ng} / \mathrm{mL} \text {. Correlation Coefficient of } \\
600.99 \text {. Retention time, } 1.7 \text { min and } 1.9 \\
\text { min. result given by BF and METO. }\end{array}$ & 59 \\
\hline
\end{tabular}




\begin{tabular}{|c|c|c|c|c|c|}
\hline $\begin{array}{l}\text { Sr. } \\
\text { No. }\end{array}$ & Drugs & $\begin{array}{l}\text { Biological } \\
\text { fluid }\end{array}$ & $\begin{array}{c}\text { Chromatographic } \\
\text { conditions }\end{array}$ & Discussion & Ref \\
\hline 4 & $\mathrm{BF}$ & $\begin{array}{l}\text { Human } \\
\text { plasma }\end{array}$ & $\begin{array}{l}\text { Kromasil C18 column } \\
(150 \times 4.6 \mathrm{~mm}, 5 \\
\mu \mathrm{m}), \text { Methanol and } \\
0.05 \% \text { phosphoric } \\
\text { acid }(40: 60 \% v / v) \\
\end{array}$ & $\begin{array}{l}\text { MingZhang etal. developed A three-phase } \\
\text { solvent bar microextraction technique } \\
\text { combined with high performance liquid } \\
\text { chromatography fluorescence detection } \\
\text { was for quantitative determination of } \\
\text { BF. METO was used as the IS. Linearity } \\
\text { obeyed in the range of } 10-100 \mu \mathrm{g} / \mathrm{mL} \\
\text { Correlation Coefficient was } 0.994 .\end{array}$ & 60 \\
\hline 5 & $\begin{array}{l}\text { CEL,BF } \\
\text { and IRB }\end{array}$ & $\begin{array}{l}\text { Human } \\
\text { plasma }\end{array}$ & $\begin{array}{l}\text { Kromasil C18 column } \\
(150 \text { x } 4.6 \mathrm{~mm}, 5 \mu \mathrm{m}) \\
\text { phosphate buffer } \\
0.1 \mathrm{M} \text { adjusted to } \\
\text { pH } 3.4 \pm 0.1 \text { with } \\
\text { hydrochloric acid }\end{array}$ & $\begin{array}{l}\text { E. Caudron et al. described method } \\
\text { for the simultaneous determination } \\
\text { of cardiovascular drugs. Solid-phase } \\
\text { extraction technique was used for } \\
\text { determination of BF. PROP was used as } \\
\text { the IS. } \\
\text { Linearity } 10-500 \mathrm{ng} / \mathrm{ml} \text { for CEL is } 5-250 \\
\mathrm{ng} / \mathrm{ml} \text { for BF and } 20-1000 \mathrm{ng} / \mathrm{mL} \text { for } \\
\text { IRB. } \\
\text { Retention time:-BF: } 7.31 \mathrm{CEL}: 5.19 \mathrm{IRB} \text { : } \\
\text { 16.32 } \\
\text { Linear Regression Coefficient (r):-CEL } \\
\text { 0.9996, BF } 0.9990 \text {, IRB } 0.9994\end{array}$ & 61 \\
\hline 6 & $\mathrm{BF}$ & $\begin{array}{l}\text { Human } \\
\text { plasma }\end{array}$ & $\begin{array}{l}\text { Chromolith RP- } \\
18 \mathrm{e}(250 \times 4 \mathrm{~mm}) \text {. } \\
\text { Kaliumdihydrogen } \\
\text { phosphate solution } \\
0.01 \mathrm{M} \text {, } \\
\text { pH } 3.5 \text { acetonitrile } \\
(77.5: 22.5 \% v / v / v)\end{array}$ & $\begin{array}{l}\text { CorneliuOniscu et al. illuminate } \\
\text { liquid- liquid extraction with diethyl } \\
\text { ether, at alkaline pH, followed by back- } \\
\text { extraction with phosphoric acid, and } \\
\text { liquid chromatography analysis with } \\
\text { fluorescence detection for BF. METO } \\
\text { used as IS in this study. } \\
\text { Linearity obeys in the range of } 3 \mathrm{ng} / \\
\mathrm{mL} \text { and } 200 \mathrm{ng} / \mathrm{mL} \text {. Retention time was } \\
4.5 \mathrm{~min} \text { and } 7.24 \text { min. } \\
\text { Correlation coefficient was found } 0.99981 \text {. }\end{array}$ & 62 \\
\hline 7 & $\begin{array}{l}\text { BF and } \\
\text { METO }\end{array}$ & $\begin{array}{l}\text { Human } \\
\text { plasma }\end{array}$ & $\begin{array}{l}\text { RP- C18 Nucleosil } \\
\text { column acetonitrile- } \\
\text { HPLC water with } \\
1.2 \%(w / v) \text { of } \\
\text { triethylamine and the } \\
\text { pH adjusted to } 3 \text { with } \\
85 \% \text { orthophosphoric } \\
\text { acid } \\
(18: 82,20: 80, \% v / v)\end{array}$ & $\begin{array}{l}\text { A. J. Brazaet al. wasdevelopedtwo } \\
\text { different liquid-liquid extractions } \\
\text { method. Fluorometric detection used for } \\
\text { the identification of BF and METOP. } \\
\text { Linearity was in the range of } 6.25-200 \\
\mathrm{ng} / \mathrm{mL} \text { for both BF and METO. } \\
\text { Retention times for BF and METO were } \\
8.7 \text { and } 3.2 \text { min. } \\
\mathrm{R} 2=0.9857 \text { and } \\
\mathrm{R} 2=0.9959 \text {. }\end{array}$ & 63 \\
\hline 8 & $\begin{array}{l}\text { CEL and } \\
\text { BF }\end{array}$ & $\begin{array}{l}\text { Human } \\
\text { skin }\end{array}$ & $\begin{array}{l}\text { C18 Nucleosil column } \\
\left(5-\mathrm{mm} 12.5 \mathrm{~cm} \_4\right. \\
\mathrm{mm}) \text {, acetonitrile and } \\
67 \mathrm{mM} \text { Sorensen's } \\
\text { phosphate buffer (pH } \\
5.0)(30 / 70 \% \mathrm{v} / \mathrm{v})\end{array}$ & $\begin{array}{l}\text { P. Modamio et al. Illustrated a } \\
\text { predetermined procedure i.e. RP-HPLC } \\
\text { with UV detection which is used for } \\
\text { identification of CEL and BF. Phosphate } \\
\text { buffer used as a standard solution. } \\
\text { Linearity was followed in the range of } \\
25-0.78 \mu \mathrm{g} / \mathrm{mL} \text {. }\end{array}$ & 64 \\
\hline
\end{tabular}


Dhandar, A.G. Chaudhari, S.R. Ganorkar, S.B. Patil, A.S.

Surana, S.J. Shirkhedkar, A.A.

\begin{tabular}{|c|c|c|c|c|c|}
\hline $\begin{array}{l}\text { Sr. } \\
\text { No. }\end{array}$ & Drugs & $\begin{array}{l}\text { Biological } \\
\text { fluid }\end{array}$ & $\begin{array}{c}\text { Chromatographic } \\
\text { conditions }\end{array}$ & Discussion & Ref \\
\hline 9 & $\mathrm{BF}$ & $\begin{array}{l}\text { Human } \\
\text { plasma }\end{array}$ & $\begin{array}{l}\text { Zorbax SB-C18 } \\
(100 \mathrm{~mm} \times 3.0 \mathrm{~mm}) \\
\text { mixture of methanol } \\
\text { and }(0.1 \%(\mathrm{v} / \mathrm{v}) \text { acetic } \\
\text { acid } \\
(40: 60 \% \mathrm{v} / \mathrm{v}) \text { in } \\
\text { water at } \\
48^{\circ} \mathrm{C}\end{array}$ & $\begin{array}{l}\text { Exp Clin Cardiol et al. was developed } \\
\text { multiple reaction monitoring (MRM) } \\
\text { mode using an ion trap mass spectrometer } \\
\text { equipped with an electro spray ion source } \\
\text { for monitoring the BF Methanol was used } \\
\text { as an internal standard.LOQ was found } \\
\text { for BF } 1.78-85.44 \mathrm{ng} / \mathrm{mL} \text {. Correlation } \\
\text { coefficient greater than } 0.993 \text {. Retention } \\
\text { Time of BF in six different lots of blank } \\
\text { plasma }(1.9,2.3,4.68,2.3,3.8,1.7 \text { min). }\end{array}$ & 65 \\
\hline
\end{tabular}

Oskar Gonzalez et al. reported 66 simultaneous analysis of several drugs usually combined in cardiovascular therapy. Plasma samples were extracted employing a simple protein precipitation extraction with acetonitrile and pravastatin was used as IS.

. $6 \mathrm{~mm}, 3 \mu \mathrm{m})$ watercontaing $0.01 \%$ formic acid and $10 \mathrm{mM}$ ammonium formate at pH 4.1

VAL and FLU.

$\begin{array}{lll}11 \quad \text { BF } & \begin{array}{c}\text { Plasma } \\ \text { serum }\end{array} & \text { stainless steel tube } \\ & & 125 \times 5 \mathrm{~mm} \\ & \text { ID) } 1 \mathrm{mM} \\ & \text { camphorsulphonic } \\ & \text { acid in methanol }\end{array}$

R. J. Eastwood et al.reported measurement 67 of bisoprolol in plasma by using high performance liquid chromatography. Tris solution, benzimidazole which is aqueous internal standard and methyl t-butyl ether mixed with the sample vortex for 30 seconds. After the centrifugation at particular portion resulting extract is analyzed on a micro particulate silica column using $1 \mathrm{mM}$ camphorsulphonic acid in methanol as the mobile phase. At $215 \mathrm{~nm}$ detection of limit and detection of quantitation can be calculated. Minimal interference from either commonly prescribed drugs or endogenous compounds can be determined.

\section{IMPURITY PROFILING ON BF [68-72]}

The impurity profiling is designed with objectives to establish specific link between two or more samples, ascending drug distribution pattern, for identification of sources of drug samples and also for monitoring the process for drug manufacturing [68]. According to the ICH guidelines impurities are matter in the product which is not active pharmaceutical ingredients or the excepient used to manufacture it [69].An impurity profile has been established for quantification of $\mathrm{BF}$ alone and in combined dosage form. There are a various types of impurities present in BF. Following explanation can be established the impurity present in $\mathrm{BF}$ and their combined dosage form. 


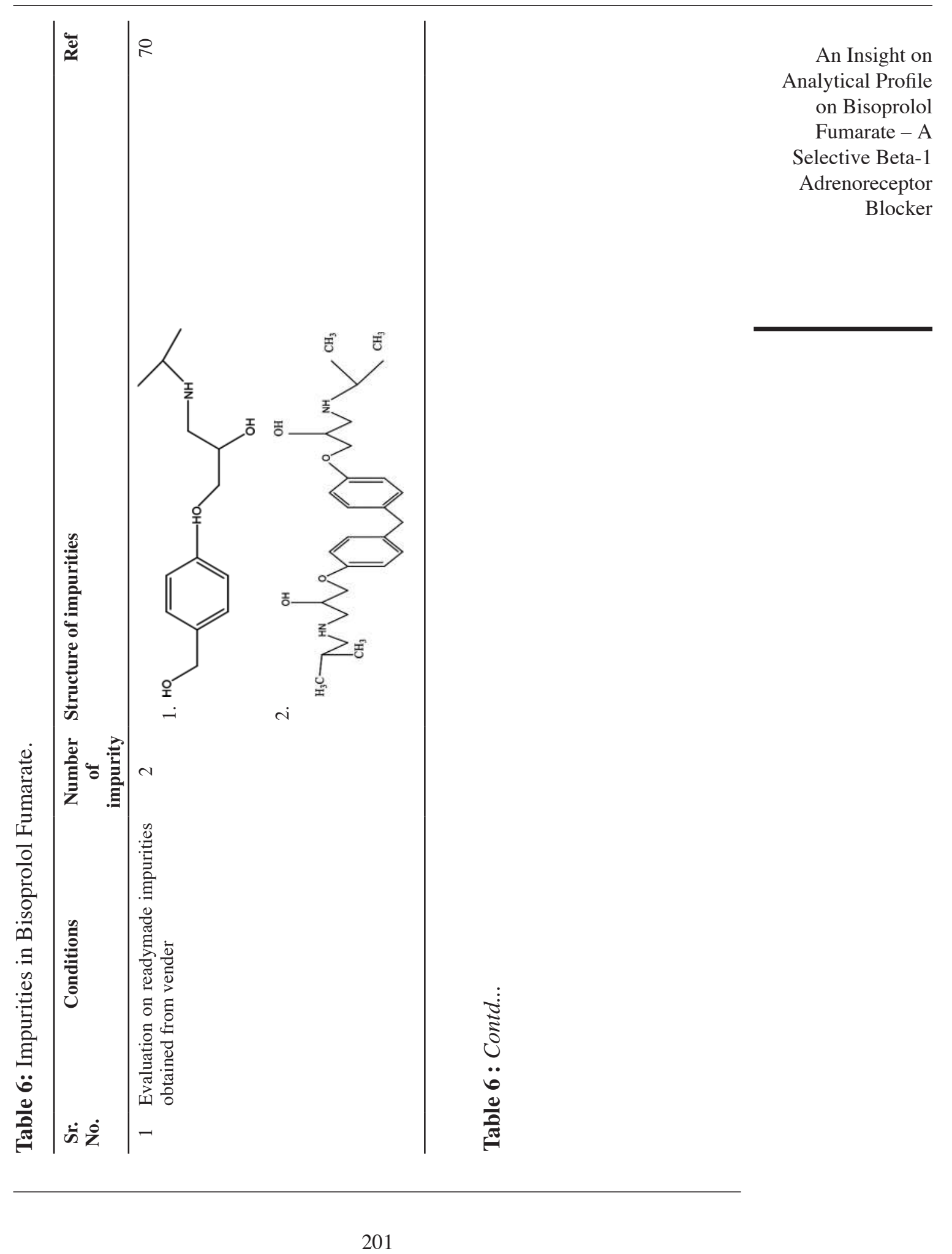


Dhandar, A.G.

Chaudhari, S.R.

Ganorkar, S.B.

Patil, A.S.

Surana, S.J.

Shirkhedkar, A.A.

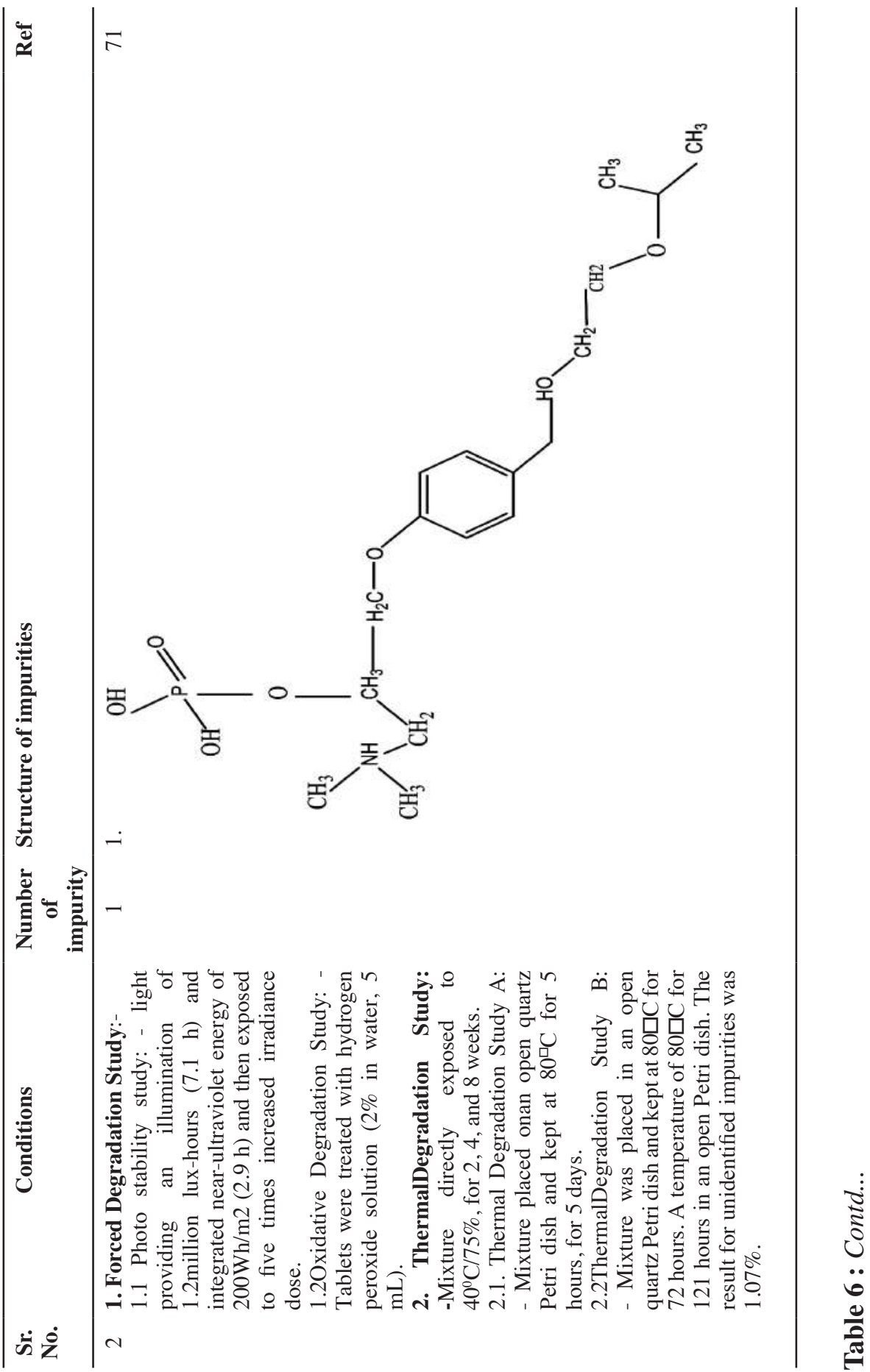




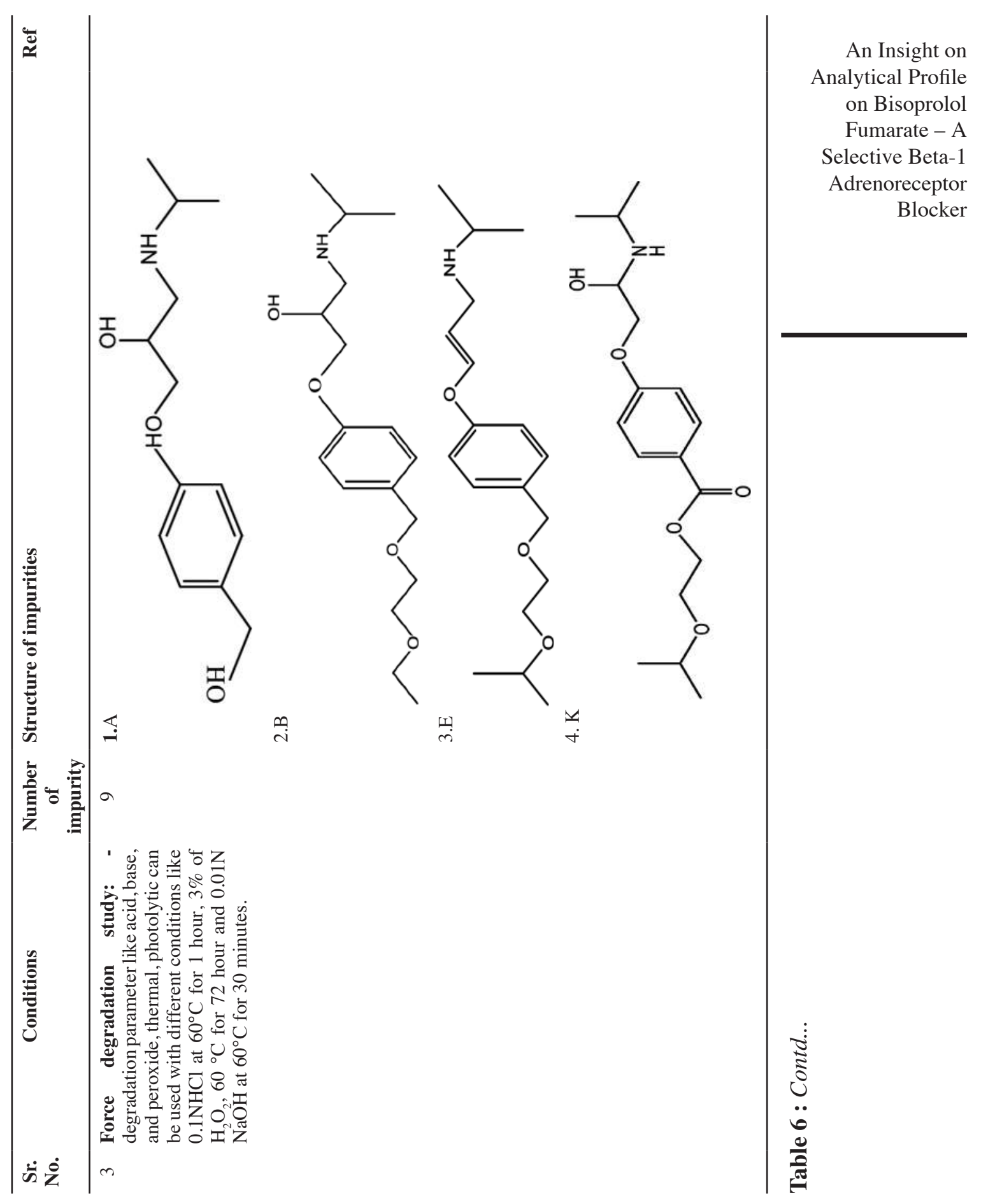


Dhandar, A.G.

Chaudhari, S.R.

Ganorkar, S.B.

Patil, A.S.

Surana, S.J.

Shirkhedkar, A.A.

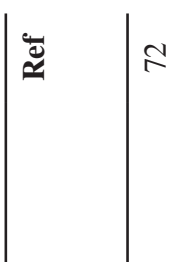

T

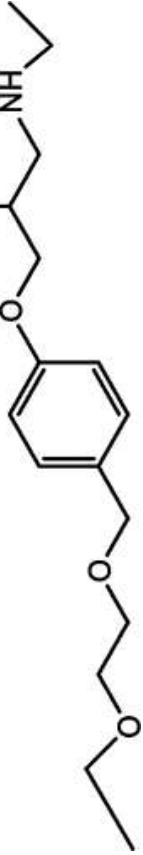

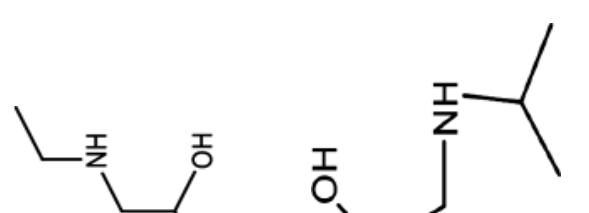

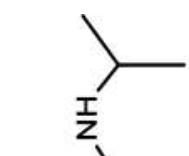

I

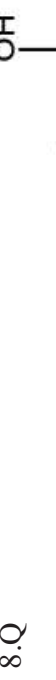

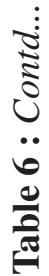




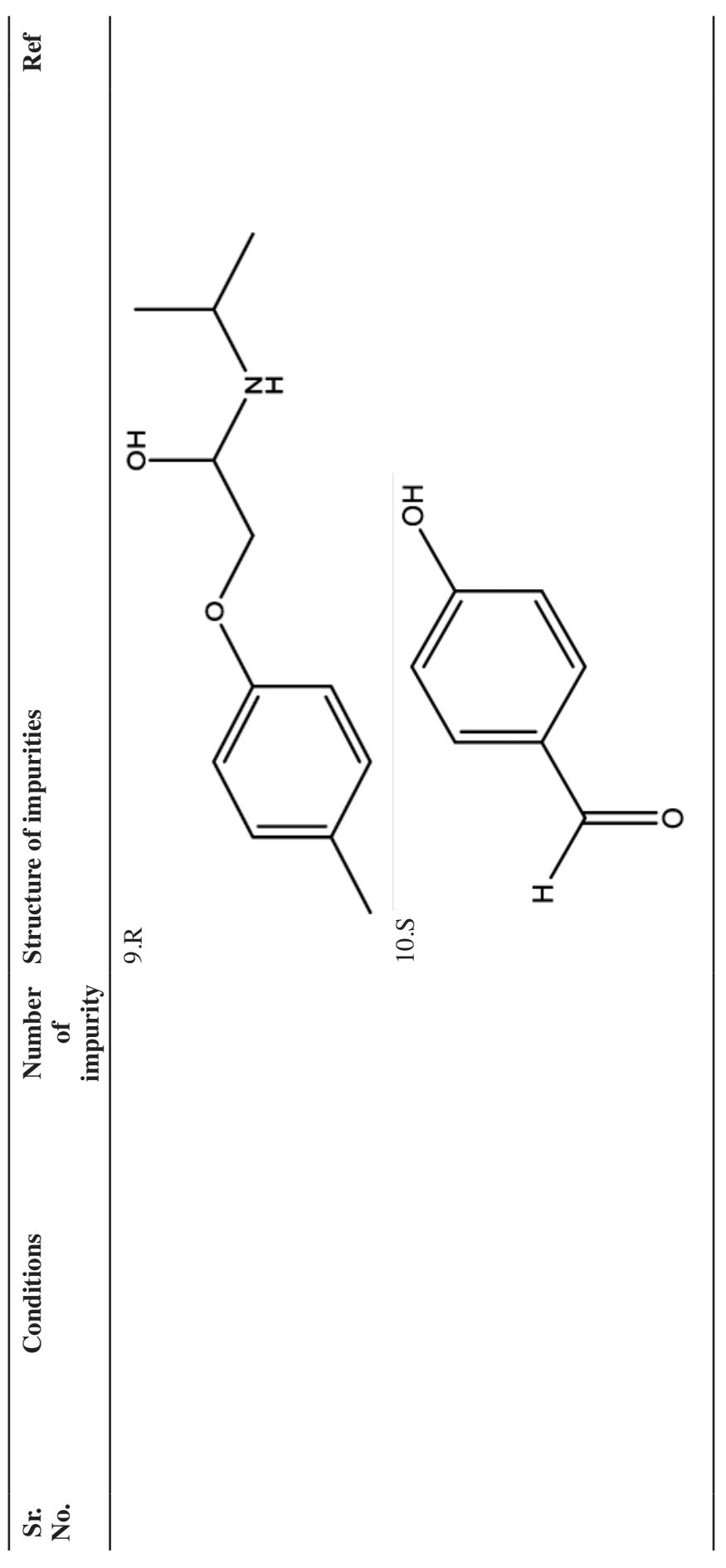

An Insight on Analytical Profile on Bisoprolol

Fumarate - A Selective Beta-1 Adrenoreceptor Blocker 
Dhandar, A.G. Chaudhari, S.R. Ganorkar, S.B. Patil, A.S.

Surana, S.J. Shirkhedkar, A.A.
Tijana Rakic et al. (2014) established hydrophilic inter face liquid chromatographic method for study of BF and its impurities $\mathrm{A}$ and $\mathrm{C}$. The chemometric strategy was resolved to systems activities and establishing the mathematical association between acetonitrile content which was present in mobile phase, $\mathrm{pH}$ of the water phase and buffer concentration in the water phase and chromatographic responses. Investigation all studies of BF from beginning to end Chromatographic technique and its impurities was established on HILIC $100 \AA$ (100 mm x $4.5 \mathrm{~mm}, 2.6 \mu \mathrm{m}$ particle size); using mobile phase mixture consist was acetonitrile - water phase $(35 \mathrm{mM}$ ammonium acetate, $\mathrm{pH}$ 4.9 manage with glacial acetic acid) $(85: 15 \mathrm{v} / \mathrm{v})$ with flow rate $1 \mathrm{~mL} / \mathrm{min}$ and analysis was performed at ambient temperature. Impurities of BF (impurity A and impurity C) are shown in Table 6 [70].

Ivana Mitrevska et al. (2017) established identification, structural interpretation and qualification of a degradation impurity RRT 0.95 of BF in film-coated tablets. The impurity of relative retention time gives at 0.95 was observed in the stress thermal degradation study of the BF film-coated tablets with identification, characterization and quantitation was performed using HPLC/DAD/ESI-MS method. The configuration of the embattled Impurity RRT 0.95 was shown in Table 6 with molecular mass of BF were 406 [71].

Venkata Narasimha Rao Ganipisetty et al. (2016) studied twelve impurities of BF and HCT and separated simultaneously using HPLC technique. Out of 12 reported impurities, five were found to be potential degradants. During the validation of stability indicating method, the focus was on the critical parameters in resolving the degradants from the main components. These parameters include Hand, temperature solvents because BF and HCT have different solubilities and polarities. The method was precise $(\mathrm{RSD}<1.0 \%)$, accurate, linear $(\mathrm{r} 2>0.999)$, robust, and stability indicating in the range of LOQ to $150 \%$ [72].

\section{ELECTROCHEMICAL METHODS:}

\subsection{Voltammetric methods for BF: [73-75]}

Rajendra N. Goyal et al.(2011) recognized an voltammetric performance of BF by using graphite electrodes were completed with single wall carbon nanotubes. In comparison to BPPGE, EPPGE gives supplementary sharp peaks in oxidation of $\mathrm{BF}$. In the variety $10-1000 \mathrm{mV} / \mathrm{s}$ in phosphate buffer solution of $\mathrm{pH} \mathrm{7.2,} \mathrm{the} \mathrm{examination} \mathrm{rate} \mathrm{of} \mathrm{repeated} \mathrm{voltammogram} \mathrm{was}$ assorted. The limits of detection were found to be $2.8 \times 10^{-7} \mathrm{M}$ and $7.3 \times 10^{-7}$ M [73].Bozal et al (2012) wasreported Simultaneous estimation of BF and HCT in their pharmaceutical formulation by applying different voltammetric, 
chromatographic, and spectrophotometric analytical methods. The level of difference pulse and square wave voltammetry techniques were used for the analysis of BF and HCT concurrently by measuring at with reference to 1400 and $1100 \mathrm{mv}$. By using different electrolytes including $\mathrm{H}_{2} \mathrm{SO}_{4}$, phosphate, acetate, and BR buffers with different $\mathrm{pH}$ values between 0.3 and 12.0 containing a constant amount of $20 \%$ methanol the voltammetric oxidation of $\mathrm{BF}$ and $\mathrm{HCT}$ were reported. $\mathrm{BF}$ was oxidized between $\mathrm{pH} 0.3$ and 10.

Rajendra N. Goyal et al. (2007)studied a BF in pharmaceutical dosage form and urine using single-wall carbon nano tubes customized glassy carbon electrode. The SWNTs-modified GCE exhibited a sharp anodic peak at a potential of $950 \mathrm{mV}$ for the oxidation of BF. In good condition linearity was found in the range of $0.01-0.1 \mathrm{mM}$ in $0.5 \mathrm{M}$ phosphate buffer solution having pH 7.2 with a correlation coefficient of 0.9789 and limit of detection was reported at $8.27 \times 10^{-7} \mathrm{M}$.

\subsection{Potentiometric method for BF: [76-77]}

Grzegorzbazylak et al. (2002) reported execution of analytical and biopharmaceutical screening data for beta-adrenergic-drug simple menting many macro cycle in HPLC Systems. In the cation-exchange HPLC technique for the studies applying acetonitrile $-40 \mathrm{mM}$ phosphoric acid (15: 85,\% v/v, as a mobile phase. By employing crossbreed polymer silica packets in RPHPLC it can be considered that promising surrogate in high throughput drug control process for examination of beta adrenergic agonist in humans and animals recommend the Potentiometric recognition [76].

Saad S.M. Hassan et al. (2003) reported the used of polymeric medium membrane sensors for purpose of $\beta$-blockers. This sensor was depending on the cations with tungs to phosphate anion as electro active materials. In some dosage form sensors are implemented for direct potentiometry of $\beta$-blockers. for the construction of the sensor plastic membrane can be made by preparing composition 2:34:64\% (w/w) ion pair complex, PVC and DOP plasticizer. The sensor was uncomplicated for the purpose of b-blockers at a concentration level as low as $10^{-7} \mathrm{~mol} \mathrm{l}^{-1}$ with an accuracy of $99.1 \pm / 1.3 \%$. [77].

\section{CONCLUSION}

The present review gives various analytical methods for the estimation of BF. A different analysis had perform which include, Bio-analytical, HPLC, HPTLC, UV/Vis-Spectroscopy, Spectroflurometry, capillary electrophoresis, stability indicating method, impurity profile and electrochemical method like voltammetric and Potentiometric method for validation of BF in bulk and in
An Insight on Analytical Profile on Bisoprolol Fumarate - A Selective Beta-1 Adrenoreceptor Blocker

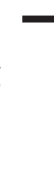


Dhandar, A.G. $\quad$ its combined pharmaceutical formulations and in plasma. Through HPLC with Chaudhari, S.R. UV detection has been found to be most studied for estimation of BF in bulk as Ganorkar, S.B. well as pharmaceutical dosage forms, while hyphenated LS-MS, Bioanalytical, Patil, A.S.

Surana, S.J. Shirkhedkar, A.A. UPLC methods are reported for quantification of BF and its metabolite in plasma and other biological fluids. HPTLC and Stability-indicating by HPLC and HPTLC are also reported in literature survey. Certain Spectrophometric methods in UV-Visible along with spectroflurometric are most often used for assessment for BF. Various types of stability indicating method and impurity profiling method have been estimated.

\section{ACKNOWLEDGEMENTS}

Authors are thankful to R.C. Patel Institute of Pharmaceutical Education and Research Shirpur, Dist: Dhule (MS) 425405 for providing necessary library facilities.

\section{CONFLICT OF INTEREST}

Authors do not have conflict of interest for this manuscript.

$\begin{array}{ll}\text { ABBREVIATIONS } \\ \text { UV } & \text { Ultra Violet } \\ \text { VIS } & \text { Visible } \\ \text { HPLC } & \text { High-Performance Liquid Chromatography } \\ \text { HPTLC } & \text { High-Performance Thin-Layer Chromatography), } \\ \text { UPLC } & \text { Ultra Pressure Liquid Chromatography, } \\ \text { LC-MS } & \text { Liquid Chromatography-Mass Spectrometry } \\ \text { IS } & \text { Internal standard } \\ \text { R } f & \text { Retention factor } \\ \text { Rt } & \text { Retention time } \\ \text { BF } & \text { Bisoprolol Fumarate } \\ \text { ML } & \text { Mili Liter } \\ \text { MP } & \text { Melting point } \\ \mu g & \text { Microgram } \\ \text { IRB } & \text { Irbesartan } \\ \text { BIS HEMI F } & \text { Bisoprolol Hemifumarate } \\ \text { AMD } & \text { Amlodipine } \\ \text { AMD B } & \text { Amlodipine Besylate } \\ \text { CELI } & \text { Celiprolol } \\ & \end{array}$




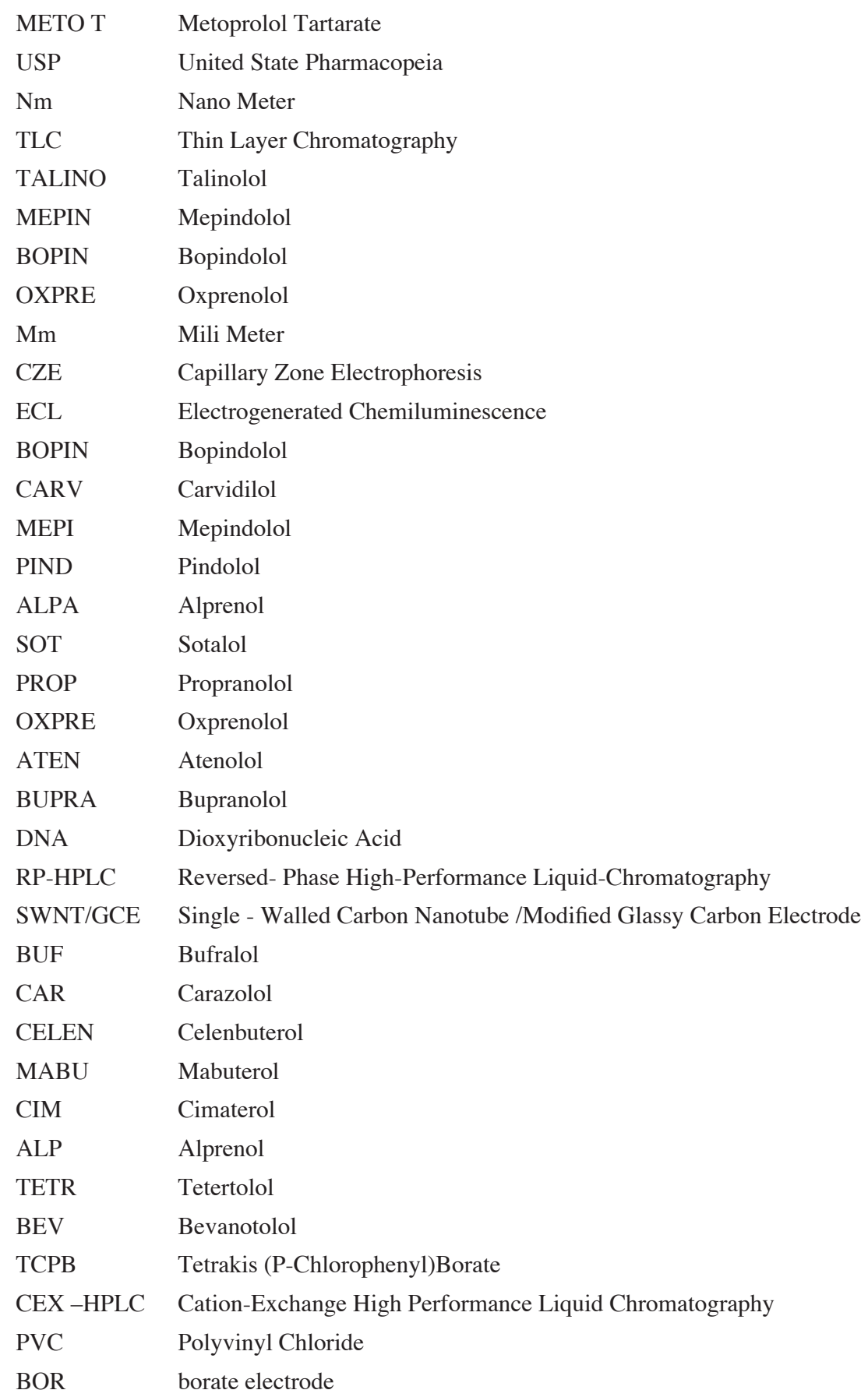


Dhandar, A.G.

Chaudhari, S.R.

Ganorkar, S.B.

Patil, A.S.

Surana, S.J.

Shirkhedkar, A.A.

\section{REFERENCES}

[1] Cheymol, G., Poirier, J.M., Carrupt, P.A., Testa, B., Weissenburger, J., Levron, J.C. and Snoeck, E.,et al. 1997. Pharmacokinetics of $\beta$-adrenoceptor blockers in obese and normal volunteers. British journal of clinical pharmacology, 43(6), 563-570. https://doi.org/10.1046/j.1365-2125.1997.00609.x

[2] Joshi, S.J., Karbhari, P.A., Bhoir, S.I., Bindu, K.S. and Das, C., 2010. RPHPLC method for simultaneous estimation of bisoprolol fumarate and hydrochlorothiazide in tablet formulation. Journal of pharmaceutical and biomedical analysis, 52(3), 362-371. https://doi.org/10.1016/j.jpba.2009.10.021

[4] Baokar, S.S., Erande, S.R. and Shaikh, G.S., 2011. Analytical method development and validation for simultaneous determination of bisoprolol fumarate and amlodipine besylate. Indo american j pharm res, 2(1), 100-110.

[5] Tjandrawinata, R.R., Setiawati, E., Yunaidi, D.A., Santoso, I.D., Setiawati, A. And Susanto,L.W., 2012. Bioequivalence study of two formulations of bisoprolol fumarate film-coated tablets in healthy subjects. Drug design, development and therapy, $\mathbf{6}, 311$.

[6] Leopold, G., Pabst, J., Ungethüm, W. and Bühring, K.U., 1986. Basic Pharmacokinetics of Bisoprolol, a New Highly Beta1-selective Adrenoceptor Antagonist. The Journal of Clinical Pharmacology, 26(8), 616-621. https://doi.org/10.1002/j.1552-4604.1986.tb02959.x

[7] Neutel, J.M., Smith, D.H. and Weber, M.A., 2001. Low-dose combination therapy: an important first-line treatment in the management of hypertension. American journal of hypertension, 14(3), 286-292.

https://doi.org/10.1016/S0895-7061(00)01310-8

[8] United state pharmacopeia (USP) by authority of the united state Pharmacopoeial convention Inc., meeting at Washington, DC, April 12-16, 2000.

[9] Panainte, A.D., Bibire, N., Tantaru, G., Apostu, M., Vieriu, M. and Dorneanu, V., 2014. A new method for the assay of bisoprolol using bromocresol green. $R E V$ CHIM-BUCHAREST, 65(8), 916-920.

[10] Bobade, P.S. and Ganorkar, S.B., 2017. Establishing Pharmaceutical Brand Variability for Bisoprolol Fumarate and Hydrochlorothiazide Combinations: As an applied Q-absorbance Spectrophotometry. Pharmaceutical Methods, 8(1).

[12] Gudruman, A.D., Murrasu, A. and Dorneanu, V., 2012. Spectrophotometric determination of bisoprolol using methyl orange as reagent. Farmacia, 60(5), 634.

[13] GawarkarPriyanka S., GavarkarPratibha S.V 2015 development and validation of uv spectrophotometric methods for simultaneous estimation of amlodipine besylate and bisoprolol fumarate in pure and tablet dosage form, International Journal of Universal Pharmacy and Bio Sciences 4(3): May-June 2015, 107-117.

[14] Gudruman, A.D.P., Bibire, N., Tantaru, G., Apostu, M., Vieriu, M. and Dorneanu, V., 2013. Validation of a New Spectrophotometric Method for the Assay of Bisoprolol Fumarateusing Tropaeolin 00. REV. CHIM. (BUCHAREST), 393-396. 
[15] Tuljarani G., GowriSankar D. v 2010 quantitative determination of bisoprolol fumarate in bulk and pharmaceutical dosage forms by Spectrophotometry, Int. J. Chem. Sci.: 8(4), 2010, 2253-2258

[16] Abdelmonem, A.A., Ragab, G.H., Hashem, H.A. and Bahgat, E.A., 2016. Spectroflurometric and spectrophotometric determination of irbesartan and bisoprolol hemifumarate independently in their tablets. UK J Pharm Biosci, 4(2), 43-52. https://doi.org/10.20510/ukjpb/4/i2/97093

[17] Ashour, S., Al-Khalil, R. and Alfares, B., 2014. Hydrochlorothiazide Used as Diuretic with Antihypertensive Agents in Pharmaceutical Preparations. Estimation by First-Order Derivative and Extractive Spectrophotometry.

[18] Akram, M., Didamony, E.L., Hafeez, S. and Saad, A., 2015. Extraction spectrophotometric determination of some antihypertensive drugs in pharmaceuticals and biological fluids using two sulphonphthalein dyes. Int $J$ Appl Pharm, 7, 10-7.

[19] EL-Didamony, A.M., Saad, M.Z. and Ramadan, G.M., 2012. Kinetic spectrophotometric determination of $\beta$-adrenergic antagonists using alkaline potassium permanganate. Main Group Chemistry, 11(4), 245-258.

[20] Atul, A.S., Rajesh, R.T. and Sanjay, J.S., 2008. Simultaneous spectrophotometric estimation of Bisoprolol fumarate and hydrochlorothiazide in tablet dosage form. Pakistan Journal of Pharmaceutical Sciences, 21(4).

[21] Joshi, S.J., Karbhari, P.A., Bhoir, S.I., Bindu, K.S. and Das, C., 2010. RPHPLC method for simultaneous estimation of bisoprolol fumarate and hydrochlorothiazide in tablet formulation. Journal of pharmaceutical and biomedical analysis, 52(3), 362-371. https://doi.org/10.1016/j.jpba.2009.10.021

[22] Bozal, B., Gumustas, M., Topal, B.D., Uslu, B. and Ozkan, S.A., 2013. Fully validated simultaneous determination of bisoprolol fumarate and hydrochlorothiazide in their dosage forms using different voltammetric, chromatographic, and spectrophotometric analytical methods. Journal of AOAC International, 96(1), 42-51. https://doi.org/10.5740/jaoacint.11-364

[23] Vora, D.N. and Kadav, A.A., 2008. Development and validation of a simultaneous HPLC method for estimation of bisoprolol fumarate and amlodipine besylate from tablets. Indian journal of pharmaceutical sciences, 70(4), 542. https://doi.org/10.4103/0250-474X.44616

[24] Siva Shankar Rao G., Parameswara Rao K. 2015. Development and Validation of RP-HPLC Method for the Assay of Bisoprolol in Pure and Formulations. Indian journal of pharmacy and pharmaceutical research 3 (1): 15-24.

[25] Rudwan, E.H., Mohammed, A.B. and Saeed, A.E., UV Derivative Spectrophotometric Method for Determination of Bisoprolol Fumarate in Bulk and Tablet Formulation.

[26] Baokar, S.S., Erande, S.R. and Shaikh, G.S., 2011. Analytical method development and validation for simultaneous determination of Bisoprolol fumarate and amlodipine besylate. Indo American J Pharm Res, 2(1), 100-110.
An Insight on Analytical Profile on Bisoprolol Fumarate - A Selective Beta-1 Adrenoreceptor Blocker

\section{(n)}


Dhandar, A.G.

Chaudhari, S.R.

Ganorkar, S.B.

Patil, A.S.

Surana, S.J.

Shirkhedkar, A.A.
[27] Mostafa A, El-Gindy A, Emara S (2017) Simultaneous Spectrophotometric Estimation of Bisoprolol Fumarate and Hydrochlorothiazide in Tablet Formulation using Partial Least-Squares, Principal Component Regression Multivariate Calibrations and RP-HPLC Methods. J Anal Pharm Res 4(6): 00124. https://doi.org/10.15406/japlr.2017.04.00124

[28] Hefnawy, M.M., Sultan, M.A. and Al-Shehri, M.M., 2006. Development of an HPLC method for the quantitation of bisoprolol enantiomer in pharmaceutical products using a teicoplanin chiral stationary phase and fluorescence detection. Journal of liquid chromatography \& related technologies, 29(20), 2901-2914. https://doi.org/10.1080/10826070600978302

[29] Raju, D.S., Vidyadhara, S., Rao, B.V. and Madhavi, D., 2016. A modified liquid chromatographic method development and validation for simultaneous estimation of bisoprolol fumarate and hydrochlorothiazide in bulk and tablet dosage form. International Journal of Pharmaceutical Sciences and Research, 7(7), 2996.

[30] Panainte, A.D., Vieriu, M., Tântaru, G., Apostu, M. and Bibire, N., fast RP-HPLC method for the determination of bisoprolol.

[31] Mahu, S.C., Spac, A.F., Ciobanu, C., Hancianu, M., Agoroaei, L. and Butnaru, E., Quantitative determination of bisoprolol fumarate by HPLC.

[32] Dobricic, V., Vulovic-Tadic, M., Jancic-Stojanovic, B., Vladimirov, S. and Cudina, O., 2016. Desirability based optimization and validation of new RP-HPLC method for simultaneous determination of bisoprolol fumarate, hydrochlorothiazide and their impurities. chromatographia, 79(9-10), 571-579.

[33] Agapova,N.N. and Vasileva,E., 1993. High-performance liquid chromatographic method for the determination of bisoprolol and potential impurities. Journal of Chromatography A, 654(2), 299-302.

https://doi.org/10.1016/0021-9673(93)83373-Z

[34] Ganipisetty, V.N.R., Jalandhar, D., Gnanadev, G., Manoj, P. and Venkata Nadh, R., 2016. A novel reversed-phase liquid chromatographic method for the simultaneous determination of potential impurities of bisoprolol fumarate and hydrochlorothiazide in a fixed dosage form. Separation Science and Technology, 51(8), 1362-1369. https://doi.org/10.1080/01496395.2016.1154873

[35] Zhou, J., Pei, W., Su, N., Liu, Q., Fu, G. and Zhang, Z., 2013. Separation of fourlol drugs by HPLC with new bonded chiral stationary column. Chinese Science Bulletin, 58(11), 1267-1273. https://doi.org/10.1007/s11434-012-5636-7

[36] Marothu, V.K., Yerramothu, P., Gorrepati, M., Majeti, S., Mamidala, S.K. and Nellutla, A., 2015, November. Application of HPLC to assess the compatibility of bisoprolol fumarate with selected excipients in mixtures by isothermal stress testing. In Annalespharmaceutiquesfrancaises 73(6): 442-451). Elsevier Masson. https://doi.org/10.1016/j.pharma.2015.05.001

[37] Oniscu, C., Vlase, C.V. and Peste, G.G., 2007. A new high performance liquid chromatographic method for determination of bisoprolol in plasma samples. Romanian Biotechnological Letters, 12(1), 3079. 
[38] Peste, G., Oniscu,C. and Vlase, A., 2010. Experimental research for determination of bisoprolol fumarate in human plasma samples using liquid chromatographytandem mass spectrometry (LC-MS/MS) technique. Romanian Biotechnological Letters, 15(2), 5141.

[39] Zhang, M., Li, Q., Ji, W., Jiang, S., Ma, C., Wang, C., Ye, J., Cui, Y., Liu, W., Bi, K. and Chen, X., 2011. Three-phase solvent bar microextraction combined with HPLC for extraction and determination of plasma protein binding of bisoprolol. Chromatographia,73(9-10), 897-903. https://doi.org/10.1007/s10337-011-1982-X

[40] Mitrevska, I., Kikovska-Stojanovska, E., Petrusevski, G., Chachorovska, M., Memed-Sejfulah, S. and Ugarkovic, S., 2017. Identification and Structural Characterization of Unidentified Impurity in Bisoprolol Film-Coated Tablets. Advances in Chemistry, 2017.

[41] Athota, R.V., Jagarlapudi, S.K. and Singampalli, M.R., 2016. Stability Indicating RP-HPLC Method for Simultaneous Assay of Bisoprolol and hydrochlorothiazide in combined tablet dosage form. International journal of pharmtech research, 9(7), 329-339.

[42] Renuka, P., Ramakrishna, M. and Babu, DM. 2016. A new chromatographic method developed stability indicating for the simultaneous estimation of bisoprolol and hydrochlorthiazide in pharmaceutical dosage forms.

[43] Bhoya,P.N. and Patelia,E.M.,2013.Chromatography development and validation of TLC-densitometry method for simultaneous estimation of Bisoprolol fumarate and Hydrochlorothiazide in bulk and tablets. Journal of Chromatography and Separation Techniques, 4(1), 1-4.

[44] Patel, D.R., Mashru, R.C. and Patel, M.M., 2011. Enantioseparation of bisoprololfumarate by TLC and HPTLC using (+)-10-camphorsulphonic acid as a chiral selector. IJPT, 3(1), 1593-1602.

[45] Yadav, S.S. and Rao, J.R., 2013. Simultaneous HPTLC analysis of bisoprololfumarate and hydrochlorthiazide in pharmaceutical dosage form. Int J Pharm PharmSci, (52), 286-90.

[46] Madhusudhanareddy, I., Bhagavan, R.M. and Rajendra, P.Y., 2012. Validated and stability indicating liquid chromatography method for quantification of bisoprolol fumarate tablet dosage form. International Journal of Pharmacy, 2(1), 64-70.

[47] Vujanović, I.K., Jelić, D., Antunović, V., Stojanović, B.J. and Ivanović, D., 2014. Stability study of amlodipine besylate and bisoprolol Fumarate in aqueous solutions. Contemporary Materials, 2(5), 212-221.

[48] Athota, R.V., Jagarlapudi, S.K. and Singampalli, M.R., 2016. Stability Indicating RP-HPLC Method for Simultaneous Assay of Bisoprolol and Hydrochlorothiazide in Combined Tablet Dosage Form. International Journal of PharmTech Research, 9(7), 329-339.

[49] Kasagic-Vujanovic, I., Stojanovic, B.J. and Ivanovic, D., 2017. Monitoring of bisoprolol fumarate stability under different stress conditions. In CMBEBIH 2017 (415-424). Springer, Singapore. https://doi.org/10.1007/978-981-10-4166-2_64
An Insight on Analytical Profile on Bisoprolol Fumarate - A Selective Beta-1 Adrenoreceptor Blocker

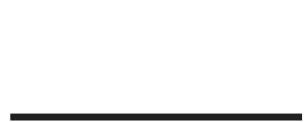


Dhandar, A.G.

Chaudhari, S.R.

Ganorkar, S.B.

Patil, A.S.

Surana, S.J.

Shirkhedkar, A.A.
[50] Kurbanoglu, S., San Miguel, P.R., Uslu, B. and Ozkan, S.A., 2014. Stabilityindicating UPLC method for the determination of bisoprolol fumarate and hydrochlorothiazide: application to dosage forms and biological sample. Chromatographia, 77(3-4), 365-371. https://doi.org/10.1007/s10337-013-2606-4

[51] Kurbanoglu, S., San Miguel, P.R., Uslu, B. and Ozkan, S.A., 2014. Stabilityindicating UPLC method for the determination of bisoprolol fumarate and hydrochlorothiazide: application to dosage forms and biological sample. Chromatographia, 77(3-4), 365-371. https://doi.org/10.1007/s10337-013-2606-4

[52] Gagyi, L., Gyeresi, A. and Kilar, F., 2006. Role of chemical structure in stereoselective recognition of beta-blockers and H1-antihistamines by human serum transferrin in capillary zone electrophoresis. Electrophoresis, 27(8), 1510-1516. https://doi.org/10.1002/elps.200500787

[53] Duan, H.B., Cao, J.T., Wang, H. and Liu, Y.M., 2015. Determination of metoprolol tartrate and bisoprololfumarate by capillary electrophoresis coupled with tris (2,2'-bipyridyl)-ruthenium (ii) electrochemiluminescence detection and study on the interaction between the drugs and human serum albumin. Analytical Methods, 7(9), 3946-3951. https://doi.org/10.1039/C5AY00336A

[54] Wang, J., Zhang, X., Pi, F., Wang, X. and Yang, N., 2009. Tris (2, 2'-bipyridyl) ruthenium (II)-bisoprolol-based electrochemiluminescence coupled with capillary zone electrophoresis. ElectrochimicaActa, 54(8), 2379-2384. https://doi.org/10.1016/j.electacta.2008.10.066

[55] Gagyi, L., Gyeresi, Á. and Kilar, F., 2008. Role of chemical structure in stereoselective recognition of $\beta$-blockers by cyclodextrins in capillary zone electrophoresis. Journal of biochemical and biophysical methods, 70(6), 1268-1275. https://doi.org/10.1016/j.jbbm.2007.10.004

[56] Bansal, S. and DeStefano, A., 2007. Key elements of Bioanalytical method validation for small molecules. The AAPS journal, 9(1), E109-E114. https://doi.org/10.1208/aapsj0901011

[57] Tatar Ulu, S. and Aydogmuş, Z., 2012. An HPLC method for the determination of bisoprolol in human plasma and its application to a pharmacokinetic study. Journal of chromatographic science, 50(7), 615-619. https://doi.org/10.1093/chromsci/bms056

[58] Chang, H., Li, J., Li, J., Guan, X., Sun, F., Qian, Z., Bi, K. and Fan, G., 2012. Simultaneous determination of amlodipine and bisoprolol in rat plasma by a liquid chromatography/tandem mass spectrometry method and its application in pharmacokinetic study. Journal of pharmaceutical and biomedical analysis, 71, 104-110. https://doi.org/10.1016/j.jpba.2012.08.012

[59] Peste, G., Bibire, N., Apostu, M., Vlase, A. and Oniscu, C., 2009. A new liquid chromatography-tandem mass spectrometry method for determination of bisoprolol in human plasma samples. BioMed Research International, 2009. https://doi.org/10.1155/2009/736327 
[60] Zhang, M., Li, Q., Ji, W., Jiang, S., Ma, C., Wang, C., Ye, J., Cui, Y., Liu, W., Bi, K. and Chen, X., 2011. Three-phase solvent bar microextraction combined with HPLC for extraction and determination of plasma protein binding of bisoprolol. Chromatographia,73(9-10), 897-903.https://doi.org/10.1007/s10337-011-1982-x

[61] Caudron, E., Laurent, S., Billaud, E.M. and Prognon, P., 2004. Simultaneous determination of the acid/base antihypertensive drugs celiprolol, bisoprolol and irbesartan in human plasma by liquid chromatography. Journal of Chromatography B, 801(2), 339-345. https://doi.org/10.1016/j.jchromb.2003.11.009

[62] Oniscu, C., Vlase, C.V. and Peste, G.G., 2007. A new high performance liquid chromatographic method for determination of bisoprolol in plasma samples. Romanian Biotechnological Letters, 12(1), 3079.

[63] Braza, A.J., Modamio, P., Lastra, C.F. and Mario, E.L., 2002. Development, validation and analytical error function of two chromatographic methods with fluorimetric detection for the determination of bisoprolol and metoprolol in human plasma. Biomedical Chromatography, 16(8), 517-522. https://doi.org/10.1002/bmc.195

[64] Modamio, P., Lastra, C.F. and Marino, E.L., 1998. Transdermal absorption of celiprolol and bisoprolol in human skin in vitro. International journal of pharmaceutics, 173(1), 141-148. https://doi.org/10.1016/S0378-5173(98)00214-2

[65] Tilea, I., Muntean, D. and Tilea, B., experimental \& clinical cardiology How to reference: Determination of Bisoprolol in Human Plasma by LC-MS/MS for Therapeutic Drug Monitoring.

[66] Saleem,K., Ali,I., Kulsum,U. and Aboul-Enein,H.Y.,2013. Recent developments in HPLC analysis of $\beta$-blockers in biological samples. Journal of chromatographic science, 51(8), 807-818. https://doi.org/10.1093/chromsci/bmt030

[67] Eastwood,R.J.,Jerman,J.C.,Bhamra,R.K.and Holt,D.W.,1990.High performance liquid chromatographic measurement of bisoprolol in plasma. Biomedical Chromatography, 4(4), 178-18. https://doi.org/10.1002/bmc.1130040415

[68] Dhangar, K.R., Jagtap, R.B., Surana, S.J. and Shirkhedkar, A.A., 2017. Review article impurity profiling of drugs towards safety and efficacy: Theory and Practice. Journal of the Chilean Chemical Society, 62(2). https://doi.org/10.4067/S0717-97072017000200024

[69] Guideline,I.H.T.,2005. Validation of analytical procedures: textand methodology. Q2 (R1), 1.

[70] Rakić, T., Jovanović, M., Tumpa, A., Jančić-Stojanović, B. and Medenica, M., Optimization of HILIC method for the analysis of bisoprolol and its impurities considering uncertainties in peak position.

[71] Mitrevska, I., Kikovska-Stojanovska, E., Petrusevski, G., Chachorovska, M., Memed-Sejfulah, S. and Ugarkovic, S., 2017. Identification and Structural Characterization of Unidentified Impurity in Bisoprolol Film-Coated Tablets. Advances in Chemistry, 2017.
An Insight on Analytical Profile on Bisoprolol Fumarate - A Selective Beta-1 Adrenoreceptor Blocker 
Dhandar, A.G.

Chaudhari, S.R.

Ganorkar, S.B.

Patil, A.S.

Surana, S.J.

Shirkhedkar, A.A.
[72] Ganipisetty, V.N.R., Jalandhar, D., Gnanadev, G., Manoj, P. and Venkata Nadh, R., 2016. A novel reversed-phase liquid chromatographic method for the simultaneous determination of potential impurities of bisoprolol fumarate and hydrochlorothiazide in a fixed dosage form. Separation Science and Technology, 51(8), 1362-1369. https://doi.org/10.1080/01496395.2016.1154873

[73] Goyal, R.N., Chatterjee, S., Singh, S.P., Rana, A.R.S. and Chasta, H., 2012. The Electrocatalytic Activity of Bare Pyrolytic Graphite and Single Wall Carbon Nanotube Modified Glassy Carbon Sensors Is Same for the Quantification of Bisoprolol Fumarate. American Journal of Analytical Chemistry, 3(02), 106. https://doi.org/10.4236/ajac.2012.32015

[74] Bozal, B., Gumustas, M., Topal, B.D., Uslu, B. and Ozkan, S.A., 2013. Fully validated simultaneous determination of bisoprolol fumarate and hydrochlorothiazide in their dosage forms using different voltammetric, chromatographic, and spectrophotometric analytical methods. Journal of AOAC International, 96(1), 42-51. https://doi.org/10.5740/jaoacint.11-364

[75] Goyal, R.N., Tyagi, A., Bachheti, N. and Bishnoi, S., 2008. Voltammetric determination of bisoprolol fumarate in pharmaceutical formulations and urine using single-wall carbon nanotubes modified glassy carbon electrode. ElectrochimicaActa, 53(6), 2802-2808.

https://doi.org/10.1016/j.electacta.2007.10.057

[76] Bazylak, G. and Nagels, L.J., 2002. Integrated acquisition of analytical and biopharmaceutical screening data for beta-adrenergic-drugs employing diversified macrocycle supported potentiometric detection in HPLC systems. Current medicinal chemistry, 9(16), 1547-1566. https://doi.org/10.2174/0929867023369475

[77] Hassan, S.S., Abou-Sekkina, M.M., El-Ries, M.A. and Wassel, A.A., 2003. Polymeric matrix membrane sensors for sensitive potentiometric determination of some $\beta$-blockers in pharmaceutical preparations. Journal of pharmaceutical and biomedical analysis, 32(1), 175-180. https://doi.org/10.1016/S0731-7085(03)00015-3 